\title{
Effect of particle size and concentration on feeding behaviour, selectivity and rates of food ingestion by the Cape anchovy Engraulis capensis
}

\author{
A. G. James ${ }^{1}$, K. P. Findlay ${ }^{2}$ \\ ${ }^{1}$ Sea Fisheries Research Institute, Private Bag X2, Rogge Bay, Cape Town, and \\ Marine Biology Research Institute, University of Cape Town, Private Bag, Rondebosch 7700, Cape Town, South Africa \\ ${ }^{2}$ Mammal Research Institute, University of Pretoria, Pretoria, South Africa
}

\begin{abstract}
Engraulis capensis (Gilchrist) is capable of both filter and particulate feeding, the latter being the dominant mode. Food concentrations required to initiate filter feeding were inversely related to particle size. Turning rate, swimming speed and feeding mode also depended on prey size. The anchovy switched from filtering to biting at a threshold prey size of 0.710 to $0.720 \mathrm{~mm}$; the feeding mode employed by the fish on prey approximating this size depended upon prey concentration. Biting clearance rates were greater than those for filtering, and the fish fed at maximum rate over most of their prey size spectrum. These results indicate that $E$. capensis had adapted its feeding behaviour to maximise food intake and to minimise energy expenditure. The selective grazing of E. capensis may have a significant effect on the structure of its prey communities.
\end{abstract}

\section{INTRODUCTION}

The anchovy Engraulis capensis (Gilchrist) forms the mainstay of the South African and Namibian purse seine fisheries. Early field work indicated that larvae and juveniles were selective, raptorial carnivores but switched to non-selective filter feeding omnivory when adults (Robinson 1966, King \& Macleod 1976). Later work refuted these findings, showing that the anchovy, although a facultative filter feeder, practised sizeselective omnivory throughout its life (James 1987).

Previous laboratory work on planktivorous fish had shown that feeding behaviour and rate of food consumption were dependent on size and density of available prey (Leong \& O'Connell 1969, O'Connell 1972, O'Connell \& Zweifel 1972, Durbin \& Durbin 1975, Janssen 1976, Holanov \& Tash 1978, Hunter \& Dorr 1982, Gibson \& Ezzi 1985). General conclusions drawn from these studies are that feeding is selective and planktivores can have a marked impact upon their prey communities. The present study was initiated to: (A) Obtain feeding rates of Engraulis capensis on differentsized food particles essential for future energy budget work; (B) confirm and elaborate on findings of an earlier field study (James 1987); (C) investigate the selective feeding behaviour displayed by the Cape anchovy.

\section{METHODS AND MATERIALS}

Schools of 19 to 48 wild anchovy Engraulis capensis (Gilchrist), mean length $100.4 \pm 5.86 \mathrm{~mm}$, were maintained in a 3 or $2 \mathrm{~m}$ diameter tank, $1.5 \mathrm{~m}$ deep, and supplied with a continuous flow of $5 \mu \mathrm{m}$ filtered seawater at ambient temperature $\left(16.2^{\circ} \mathrm{C} \pm 0.4 \mathrm{C}^{\circ}\right)$. The size of the schools varied due to mortality and sacrifices for other experiments. Tanks were restocked 6 times during the 2 yr experimental period using the technique of James et al. (1988).

The $3 \mathrm{~m}$ tank was situated in a laboratory illuminated by a $150 \mathrm{~W}$ incandescent bulb $\left( \pm 40 \mu \mathrm{Em}^{-2} \mathrm{~s}^{-1}\right)$ on a $12 \mathrm{~h}$ light $/ 12 \mathrm{~h}$ dark cycle. The $2 \mathrm{~m}$ tank was in an outside working area covered by $55 \%$ shadecloth and was subject to the ambient light cycle (70.6 to $160 \mu \mathrm{E}$ $\mathrm{m}^{-2} \mathrm{~s}^{-1}$ ). Both tanks had a porous airline around the circumference which produced a continuous fine bubble curtain up the sides. Preliminary tests using Artemia salina nauplii indicated that the combination of bubble curtain and swimming action of the fish effectively mixed the tanks contents and maintained a uniform prey distribution for the duration of the experiments (up to $5 \mathrm{~h}$ ).

The anchovy were maintained on a diet of dry trout pellets, beef liver, anchovy or rock lobster offal mixture 
(James 1988), frozen zooplankton and occasionally live Artemia salina and wild zooplankton when available.

All food types used in the experiments were reared in the Institute's culture facility. Phytoplankters used were Chaetoceros spp., a chain-forming genus, and the solitary pennate Thallasionema sp. Zooplankters were Artemia salina (cysts, nauplii, juveniles and adults), calanoid copepods Paracartia africana, Paracalanus crassirostris, Calanoides carinatus and Pseudodiaptomus hessi, and the rotifers Brachionus plicatilis and Synchaeta sp. Wild Talorchestia capensis and Euphausia lucens were maintained in the culture facility for use in one experiment. The diatoms ranged in size from 0.0114 to $0.1140 \mathrm{~mm}$, the zooplankton from 0.129 to $16.422 \mathrm{~mm}$. Phytoplankton was cultured in 5 to 3001 batches, zooplankton in 200 to 25001 containers, depending on the volume required. All water used for culturing was filtered through $0.45 \mu \mathrm{m}$ millepore filters.
Prior to experimentation, fish were starved for 6 to $36 \mathrm{~h}$. Sides and bottom of the tanks were thoroughly scrubbed and vacuumed the day before to remove attached growth. This procedure was repeated 2 to $3 \mathrm{~h}$ before the start of the experiment and the tank flushed with filtered seawater. The $5 \mu \mathrm{m}$ filter removed any potential food particles from the seawater. Just before the start, the water supply was cut off and the tank lowered to a suitable level, depending on the number of fish in the tank and the density of food required (Table 1).

Food was introduced through 4 feeding ports distributed evenly around the side of the tank. The bubble curtain ensured thorough mixing within 1 to $2 \mathrm{~min}$ of introduction. The fish settled down and started to feed within $5 \mathrm{~min}$ of food addition to the tank. The experiment was considered to have commenced $(\mathrm{T}=0)$ when the majority of fish had begun feeding.

Plankton samples were taken at $\mathrm{T}=0$ and at appro-

Table 1. Summary of information collected for each of the experimental feeding trials

\begin{tabular}{|c|c|c|c|c|c|c|c|c|c|c|c|}
\hline \multirow[t]{2}{*}{ Expt. } & \multirow{2}{*}{$\begin{array}{l}\text { No. of } \\
\text { fish }\end{array}$} & \multicolumn{2}{|c|}{ Tank } & \multirow{2}{*}{$\begin{array}{c}\text { Initial } \\
\text { time } \\
\text { (h) }\end{array}$} & \multirow{2}{*}{$\begin{array}{c}\text { Light level } \\
\left(\mu \mathrm{Em} \mathrm{m}^{-2} \mathrm{~s}^{-1}\right)\end{array}$} & \multirow{2}{*}{$\begin{array}{l}\text { Starv. } \\
\text { time } \\
\text { (h) }\end{array}$} & \multirow[b]{2}{*}{ Type } & \multirow[b]{2}{*}{$\begin{array}{l}\text { Size } \\
(\mathrm{mm})\end{array}$} & \multirow{2}{*}{$\begin{array}{c}\text { Method of } \\
\text { measuring } \\
\text { swimming speed }\end{array}$} & \multicolumn{2}{|c|}{ Food } \\
\hline & & $\begin{array}{l}\text { dia. } \\
(\mathrm{m})\end{array}$ & $\begin{array}{l}\text { vol. } \\
\text { (1) }\end{array}$ & & & & & & & Dry wt & $\mathrm{C} / \mathrm{N}$ \\
\hline 2 & 46 & 3.0 & 3535 & $10: 00$ & 40 & 24 & C. carinatus & 2.490 & Stopwatch & + & - \\
\hline $3 \mathrm{~A}$ & 46 & 3.0 & 3535 & $10: 00$ & 40 & 24 & P. africana & 1.160 & Stopwatch & + & - \\
\hline B & & & & & & & C. carinatus & 2.285 & & & \\
\hline 4 & 46 & 3.0 & 3535 & $10: 00$ & 40 & 24 & A. salina & 0.411 & Stopwatch & + & - \\
\hline 5 & 46 & 3.0 & 3535 & $10: 00$ & 40 & 24 & A. salina & 0.530 & Stopwatch & + & - \\
\hline 6 & 46 & 3.0 & 3535 & $10: 00$ & 40 & 24 & P. hessi & 0.910 & Stopwatch & + & - \\
\hline $7 \mathrm{~A}$ & 46 & 3.0 & 3535 & $10: 00$ & 40 & 24 & A. salina & 0.600 & Stopwatch & + & - \\
\hline B & & & & & & & A. salina & 0.510 & & & \\
\hline 8 & 46 & 3.0 & 3535 & $10: 00$ & $40 /<0.01$ & 12 & A. salina & 0.448 & Stopwatch & + & - \\
\hline 9 & 46 & 3.0 & 3535 & $12: 00$ & 40 & 24 & A. salina & 7.110 & Stopwatch & + & - \\
\hline 10 & 46 & 3.0 & 3535 & $12: 00$ & $<0.01$ & 24 & A. salina & 7.732 & Stopwatch & + & - \\
\hline 11 & 46 & 3.0 & 3535 & $10: 00$ & 40 & 24 & A. salina & 0.540 & - & + & + \\
\hline 12 & 45 & 3.0 & 3535 & $10: 00$ & 40 & 6 & A. salina & 0.541 & Stopwatch & + & - \\
\hline 13 & 41 & 3.0 & 3535 & $10: 00$ & 40 & 24 & B. plicatilis & 0.256 & Stopwatch & + & + \\
\hline $14 \mathrm{~A}$ & 48 & 2.0 & 1570 & 09:00 & ca 100 & 24 & A. salina & 0.740 & Stopwatch & + & + \\
\hline B & & & & & & & A. salina & 0.902 & & & \\
\hline C & & & & & & & A. salina & 1.105 & & & \\
\hline D & & & & & & & A. salina & 1.413 & & & \\
\hline $15 \mathrm{~A}$ & 30 & 2.0 & 1005 & 09:00 & ca 100 & 36 & Synchaeta sp. & 0.129 & Film & + & + \\
\hline B & & & & & & & A. salina & 0.544 & & & \\
\hline C & & & & & & & cysts & 0.224 & & & \\
\hline $16 \mathrm{~A}$ & 30 & 2.0 & 911 & 09:00 & ca 100 & 36 & A. salina & 0.711 & Film & + & + \\
\hline B & & & & & & & cysts & 0.225 & & & \\
\hline $17 \mathrm{~A}$ & 29 & 2.0 & 958 & 09:00 & ca 100 & 36 & Chaetoceros & 0.093 & Film & + & + \\
\hline B & & & & & & & Thallassionema & 0.040 & & & \\
\hline $18 \mathrm{~A}$ & 29 & 2.0 & 707 & 09:00 & ca 100 & 36 & A. salina & 0.725 & Film & + & + \\
\hline B & & & & & & & A. salina & 0.893 & & & \\
\hline C & & & & & & & A. salina & 1.071 & & & \\
\hline D & & & & & & & A. salina & 1.261 & & & \\
\hline $\mathrm{E}$ & & & & & & & cysts & 0.226 & & & \\
\hline $\mathrm{F}$ & & & & & & & P. crassirostris & 0.484 & & & \\
\hline $19 \mathrm{~A}-\mathrm{J}$ & 19 & 2.0 & 613 & 09:00 & ca 100 & 36 & Chaetoceros & $0.011-0.114$ & Film & + & + \\
\hline & & & & & & & 1 to 10 cell chains & & & & \\
\hline
\end{tabular}


priate intervals thereafter until feeding ceased. Two different sampling methods were used: (1) Phytoplankton was sampled by collecting $5 \times 100 \mathrm{ml}$ aliquots with a syringe randomly throughout the tank at each time interval. The samples were preserved in $4 \%$ formalin and later chains of different lengths were enumerated according to Utermöhl as described by Hasle (1978). Cell dimensions were measured to calculate cell volume, and modified Strathman equations (Parsons et al. 1984 ) employed to convert cell volume to carbon content. Pre-experimental samples were used to determine carbon and nitrogen contents of the phytoplankton. (2) Zooplankton sampling employed a perspex tube (95 mm internal diameter, $1.1 \mathrm{~m}$ long) which mated with $37 \mu \mathrm{m}$ mesh cups spread randomly across the bottom of the tank. After mating, the combination was withdrawn from the tank, concentrating the zooplankton on the mesh. At each time interval 3 to 5 samples were taken and preserved in $4 \%$ formalin for subsequent counting and measuring using a dissecting microscope. Pre-experimental samples of the food were collected and counted, measured and dried at $60^{\circ} \mathrm{C}$ for $24 \mathrm{~h}$ to obtain a mean dry weight per individual for each size class of prey offered as food. Experimental samples were then converted to $\mu \mathrm{g}$ dry weight $1^{-1}$ accordingly. In several cases pre-experimental samples were further examined to obtain carbon and nitrogen contents of the food (Table 1).

Continual observations of schooling behaviour and swimming speed were made before and during each experiment. Swimming speeds were measured by using either a stopwatch or a $1.0 \times 0.6 \mathrm{~m}$ grid marked in $0.1 \mathrm{~m}$ squares and an $8 \mathrm{~mm}$ movie camera at 18 frames $\mathrm{s}^{-1}$ (Table 1), in which case the fish were filmed for 10 to $15 \mathrm{~s}$ as they passed over the grid. Changes in direction, defined as deviation of more than $20^{\circ}$ from the direction of motion recorded during the previous 6 film frames (1/3 s) were recorded and used to measure the turning rate (turns fish ${ }^{-1} \mathrm{~min}^{-1}$ ) of the feeding fish. Experiments were aborted if fish did not feed or displayed schooling behaviour inconsistent with the norm established during preliminary work. Experiments were terminated when all fish had ceased to feed.

To investigate the levels of food required to initiate feeding of a school, small aliquots of prey were introduced to the tank sequentially at 3 to $5 \mathrm{~min}$ intervals, with subsequent samples collected for enumeration, until at least $50 \%$ of the school was observed to be feeding. This exercise was carried out either before the start of a feeding trial (Expts 13 and 19) or constituted a separate experiment (Expt 11).

Reactive distances (Holling 1966) of the anchovy to prey were measured by placing 1 to 2 prey in 11 of water introduced to the tank at varing distances from the fish by means of a funnel and a submerged pipe.
These data were collected in the $3.0 \mathrm{~m}$ tank under the same light conditions as the feeding experiments (Table 1), and film was used to record behaviour and to measure the reactive distance. Each prey type was offered on 15 separate occasions.

\section{RESULTS}

\section{Feeding behaviour}

Engraulis capensis employ a burst and glide swimming technique described by Leong \& O'Connell (1969) for Engraulis mordax, consisting of a series of 4 to 5 tail beats followed by a glide. When accelerating, the number of tailbeats may increase to as many as 10 . The swimming behaviour was not affected by the presence of observers either during feeding or when food was absent, provided that sudden movements around the tank were avoided. The fish were most easily disturbed when food was absent or depleted at the end of a trial.

In the absence of food, Engraulis capensis schooled in the midwater of the tank with individuals executing few independent changes in direction. The schools tended to be twice as long as they were broad. Individual fish would occasionally 'gape' - opening their mouths wide and flaring the opercula for 0.2 to $1.0 \mathrm{~s}-$ in the absence of food. This gaping reduced the fish's swimming speed, neccessitating an acceleration to catch up with the school. The swimming speed of undisturbed fish ranged between 0.73 body lengths $\mathrm{s}^{-1}$ $\left(\mathrm{BL} \mathrm{s}^{-1}\right)$ and $1.88 \mathrm{BL} \mathrm{s}^{-1}$; the mean for all experiments was $1.695 \pm 0.591 \mathrm{BL} \mathrm{s}^{-1}$.

The feeding mode employed by Engraulis capensis depended primarily on food size. Phytoplankton and microzooplankton $(<0.710 \mathrm{~mm})$ elicited filter, larger zooplankton $(>0.720 \mathrm{~mm})$ particulate feeding. The fish generally fed in the midwater, but observations during preliminary work demonstrated that E. capensis was capable of obtaining prey both from the bottom of the tank and the water's surface.

\section{Filter feeding}

When phytoplankton or microzooplankton were introduced to the tank the fish began to gape frequently, similar to the behaviour noted by Durbin \& Durbin (1975) for Brevoortia tyrannus. If the concentration of food was below some threshold level this gaping soon ceased. If above then the school readily started to filter feed. A filtering bout commenced with the mouth opening wide, the protrusion of the lower 
jaw and the opercula flaring. When observed from above the head was tulip-shaped as described by Gibson \& Ezzi (1985) for filter feeding Clupea harengus. As the mouth opened the tail beat strongly at a greater amplitude than during undisturbed swimming. Filtering continued for 0.4 to $3.0 \mathrm{~s}$ and 3 to 12 tail beats accompanied each bout. The mouth closed just before the end of the last tail beat and a short glide followed. Changes in direction during filtering occurred at the beginning or end of the glide. The fish schooled more densely while filtering, and the shape of the school changed so that it was ca 1.5 to 2 times as broad as it was long.

When feeding on phytoplankton, neither swimming nor turning differed significantly from the non-feeding rates (Fig. $1 \mathrm{a}, \mathrm{d} ; \mathrm{F}=0.49, p>0.05$ ). There was no correlation between turning rate and food concentration, the slope not being significantly different from zero $(\mathrm{F}=0.1, p>0.05$; Fig. $2 \mathrm{a})$, implying that there was no orientation towards the food particles present in the water. The only discernible differences between the undisturbed state and feeding on phytoplankton were the short filtering bouts, and altered density and shape of the school.

Swimming speeds during filtering on microzooplankton were faster than the undisturbed values $\left(2.060 \pm 0.826 \mathrm{BL} \mathrm{s}^{-1}\right.$, Fig. 1d). There was a significant correlation between the rate of turning and the food concentration $(\mathrm{F}=35.2, p<0.05$, Fig. $2 b)$, indicating that the fish orientated themselves towards food particles to some degree. This suggestion is supported by observations during preliminary experiments when patches of food developed in the tanks due to inadequate mixing. The fish concentrated their feeding activity in the areas of high food density, making sharp turns to maintain themselves in these regions. Similar
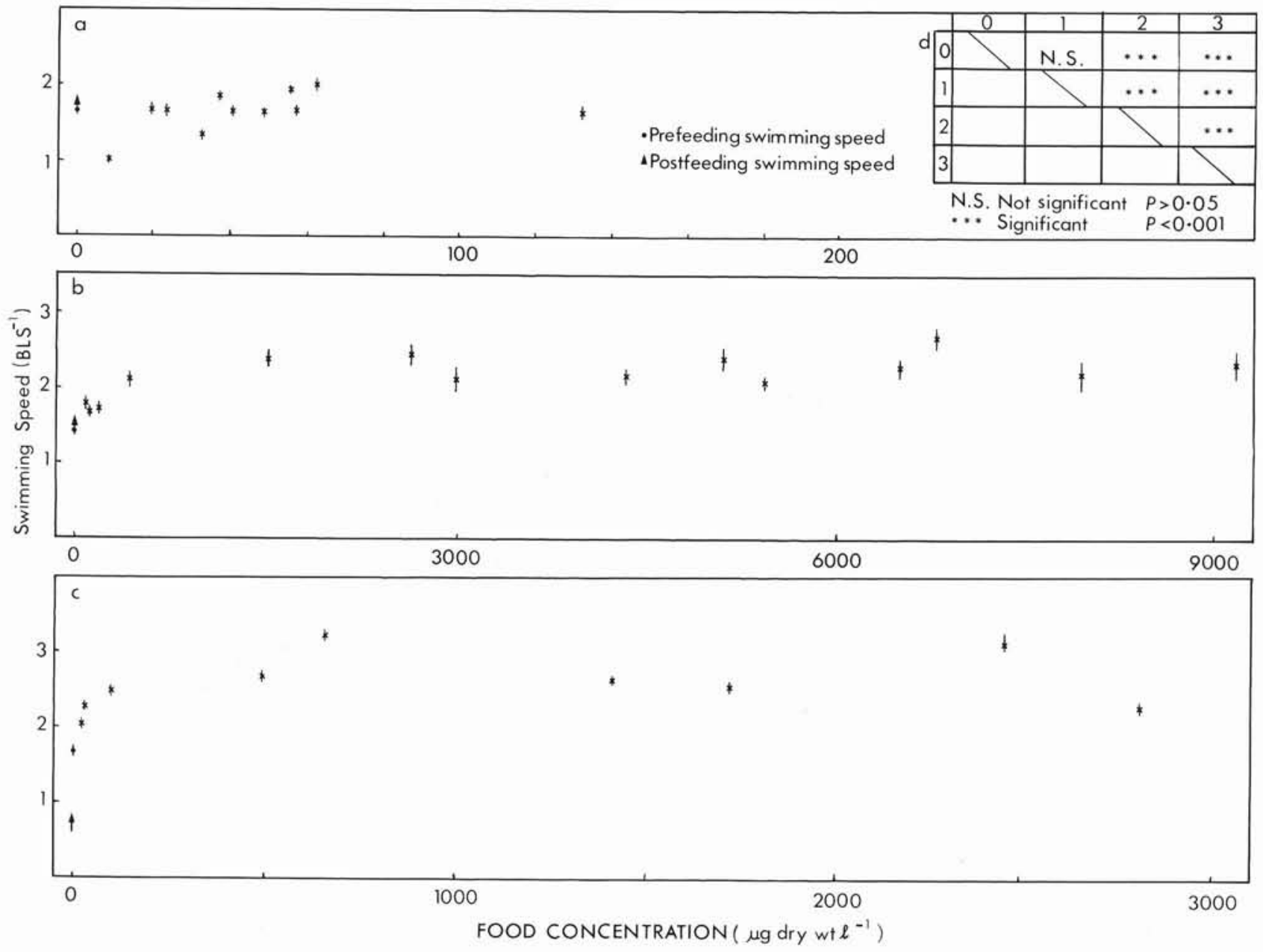

Fig. 1. Engraulis capensis. Swimming speeds of feeding anchovy as a function of food concentrations. (a) Filter feeding on Chaetoceros sp. 1 to 10 cell chains (Expt 19). (b) Filter feeding on Artemia salina nauplii and cysts (Expt 16). (c) Particulate feeding on A. salina juveniles (Expt 18); bars: $95 \%$ confidence limits, (d) Results of F-tests comparing differences in swimming speeds of (0) non-feeding fish and fish feeding on (1) phytoplankton, (2) microzooplankton and (3) mesozooplankton. Only experiments during which film was used to record behaviour have been analysed 

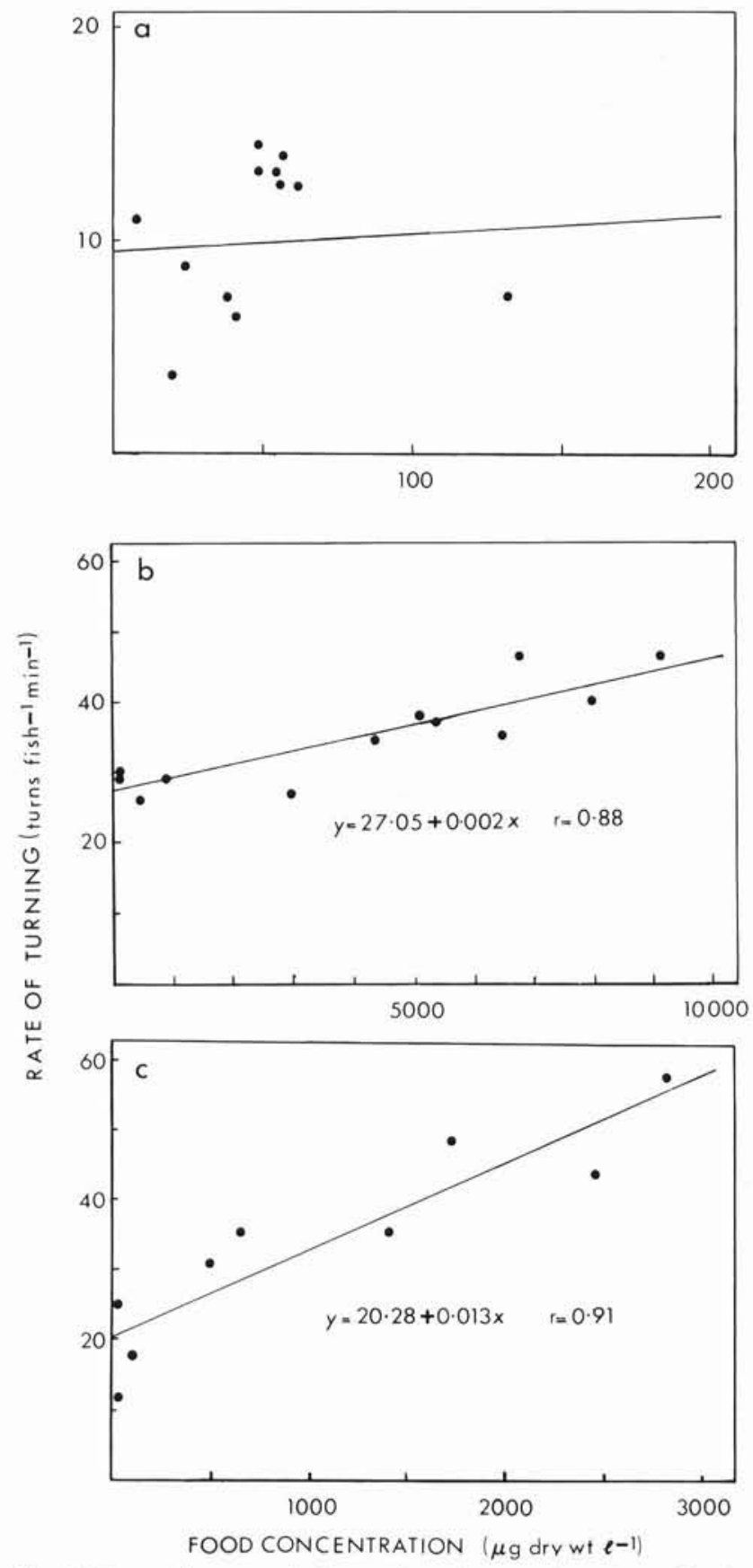

Fig. 2. Engraulis capensis. Rate of turning as a function of food concentration. (a) Filter feeding on Chaetoceros sp. 1 to 10 cell chains (Expt 19). (b) Filter feeding in Artemia salina nauplii and cysts (Expt 16). (c) Particulate feeding on A. salina juveniles (Expt 18)

activity was noted when water which had contained zooplankton or washings of frozen zooplankton were introduced to the tank. The fish moved to the area of tainted water, gaping frequently before losing interest. This behaviour further suggests that there may be a chemical cue to trigger filtering, but that the presence of particles, possibly sensed by mechanoreceptors on the gillrakers, is required to stimulate its continuation. The elevated swimming speeds remained constant over a wide range of food concentrations, although there was considerable variation around the mean (Fig. 1B). A sudden change in light intensity during one trial (Expt 8) due to power failure indicated that light intensity had no effect on schooling and feeding behaviour. The clearance rate obtained from this trial was similar to those of trials conducted in light conditions with the same food type.

\section{Particulate feeding}

Schooling broke down immediately after the initiation of particulate feeding with the fish continually changing direction independently to attack prey. The initial explosion of feeding activity was similar to the feeding frenzy described by Leong \& O'Connell (1969) for Engraulis mordax and Durbin \& Durbin (1975) for Brevoortia tyrannus. After 5 to 10 min the fish formed a loose aggregation which moved rapidly around the tank, acting independently within this structure, turning frequently to attack prey. This behaviour was modified towards the end of a trial when the fish began to school more cohesively, but the swimming speed remained elevated and feeding continued.

Swimming behaviour was strongly modified during particulate feeding. It was characterised by almost continual large amplitude tail beats interspersed with sporadic, very short glides which preceded strikes at prey. During biting the mouth started to open as the glide commenced and the prey was sucked into the mouth with the surrounding water and swallowed whole, the water exiting through the opercula, which were slightly flared after prey capture.

Swimming speeds were significantly greater than those recorded for both undisturbed and filter feeding states $\left(2.412 \pm 0.700 \mathrm{BL} \mathrm{s}^{-1}\right.$, Fig. 1d) and were independent of the food concentration (Fig. 1c). The numerous turns, which were closely correlated to the concentration of food ( $\mathrm{F}=34.9, p<0.05$, Fig. $2 \mathrm{c})$ and appeared to be primarily concerned with orientation towards prey items, were all executed before the start of the glide. There was a significantly higher degree of orientation during particulate than during filter feeding $\left(t \alpha_{(2)} 19=4.05, p<0.001\right.$, Fig. $\left.2 b, c\right)$. However, no differences in feeding behaviour were observed between light (Expt9) and dark (Expt 10) trials using the same food type. Indeed, clearance rate was greater during the dark experiment (Table 3 ), suggesting that Engraulis capensis either has extremely acute vision or that another sensory organ, such as the lateral line, plays an important role in prey location. 
Fig. 3 presents data concerning the distance over which Engraulis capensis can detect and will react to the presence of prey of differing sizes. The reactive distance tended to increase if the same prey type was offered on consecutive occasions. Therefore different prey items were offered in a random order to avoid this. These data were difficult to quantify and can only be considered as rough estimates of reaction distances. The results show that prey size is a primary factor influencing prey location and orientation of the fish during biting. There is a threshold size (ca $8.00 \mathrm{~mm}$ ), above which reactive distance is independent of prey size.

\section{Initiation of feeding}

Very low threshold concentrations were required to initiate particulate feeding on larger prey ( $>$ ca 0.720 $\mathrm{mm})$. The anchovy attacked even single prey items introduced to the tank ( 1 copepod $3.54 \mathrm{~m}^{-3}$ ), making large deviations from their original path to capture the item (Fig. 3). The threshold concentrations necessary to initiate filter feeding on smaller items $(<\mathrm{ca} 0.710 \mathrm{~mm}$ ) were inversely related to prey size in terms of numbers and biomass (Fig. 4).

\section{Termination of feeding}

Engraulis capensis terminated filter feeding at levels below those required for initiation (Table 2). The threshold concentrations for a wide range of prey were similar and independent of particle size. Four trials using Artemia salina cysts (Expts 15C and 16B), Synchaeta spp. (15A) and Chaetoceros and Thallassionema spp. (Expt 17A, B) - as food produced elevated terminal concentrations (Table 2). In the former experiments, the high values were due to the cysts being unsuitable food, and feeding activity ceased when the suitable prey had been depleted. The low value for cysts obtained from Expt 18E was due to the cysts being ingested accidentally as the fish continued to pursue their preferred prey. In no instance did the anchovy feed on the cysts alone after the removal of the other prey types. In the latter cases, the fish displayed feeding behaviour, but with a lower incidence of filtering than was expected and the fish did not significantly reduce the food concentrations during the trials.

Termination of filter feeding on zooplankton was marked by rapid return to non-feeding behaviour, with 2 to 5 min elapsing between the first noticeable signs of a reduction in activity and its complete cessation. There was no such definite termination when phytoplankton was the food, when the incidence of filtering slowly declined and the shape of the school gradually reverted to the undisturbed configuration utntil non-feeding behaviour predominated.

During particulate feeding on particles $>1.20 \mathrm{~mm}$, feeding activity was only terminated after all the food had been removed from the tank (Table 2). When prey between 0.720 and $1.20 \mathrm{~mm}$ were present, feeding apparently ceased at concentrations exceeding those required to initiate biting and were generally higher than the terminal concentrations recorded for filtering upon smaller prey (Table 2). This suggests that either factors other than prey size, such as state of hunger, influence the termination of feeding activity, or, more likely, the short reactive distances due to the small size of the prey resulted in a reduction in the predator-prey encounter rate, causing feeding to fall to such low levels that the observers terminated the trials prematurely. The fish probably cleared the remaining food from the tank at a low rate after termination of the trial.

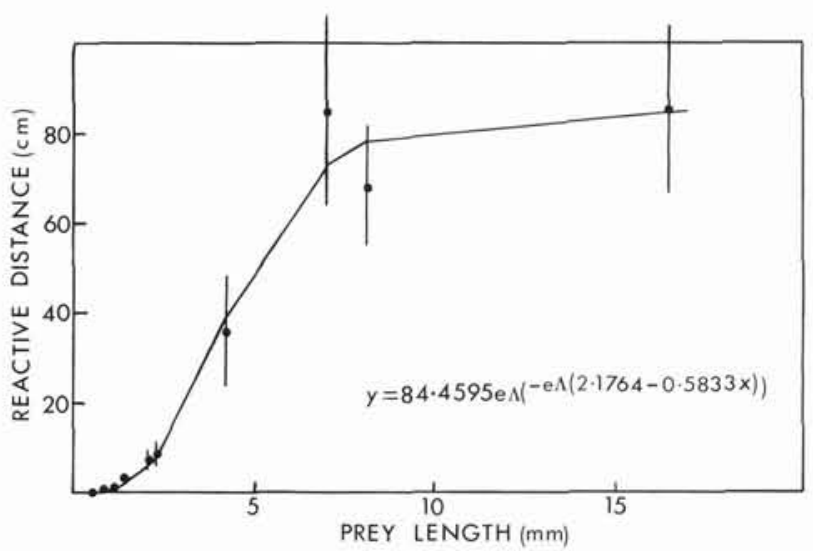

Fig. 3. Engraulis capensis. Reactive distances of $10.04 \mathrm{~cm}$ anchovy as a function of prey length. Each point is the mean of 15 separate estimates; bars: $95 \%$ confidence limits

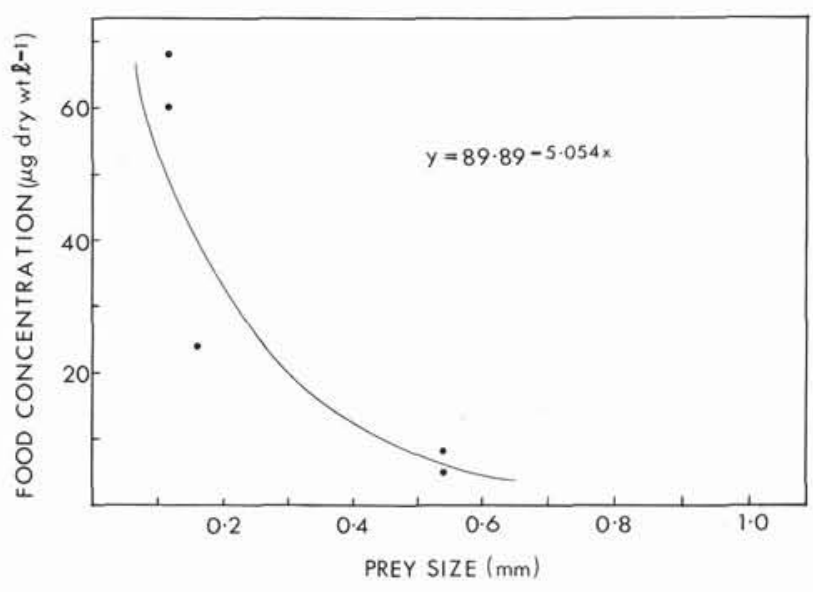

Fig. 4. Engraulis capensis, Concentration of food required to initiate filter feeding as a function of prey size 


\section{Feeding rates}

Feeding activity after introduction of food resulted in an exponential decline in the food concentration (Figs. 5 to 9), indicating that a constant proportion was removed per unit time, regardless of the feeding mode or particle size. The slope of the semi-log plot is the mean instantaneous feeding rate, $g$. The clearance rate (Strickler 1985) or the volume swept clear per unit time, F (Harvey 1937, Frost 1972, Durbin \& Durbin 1975), may be determined from the relationship:

$$
F=V g / N
$$

where $V=$ tank volume; $N=$ no. of grazers. The term 'clearance rate' will be adopted for this work rather than volume swept clear per unit time, as the former makes no assumption about feeding behaviour while the latter implies filtering activity. The clearance rate is an estimate of the volume from which all the food particles would have to be removed per unit time to produce the observed ingestion rates, $I$ (Durbin \& Durbin 1975, Marin et al. 1986) where $I=[C t] F_{;}[C t]=$ food concentration at time $t$. Following the reasoning of Durbin \& Durbin (1975) all clearance rates have been expressed on a per fish rather than per gram basis.

\section{Filter feeding}

The results of the 2 phytoplankton feeding trials are displayed in Table 3 and Fig. 5. During Expt 17, Engraulis capensis removed neither the single cells of Thalassionema sp. $(40 \mu \mathrm{m})$ nor the 11 cell chains of a Chaetoceros sp. $(93 \mu \mathrm{m})$ from the water, even though

Table 2. Concentrations of food in the tank at termination of feeding

\begin{tabular}{|c|c|c|c|c|c|c|}
\hline \multirow[t]{2}{*}{ Feeding mode } & \multirow[t]{2}{*}{ Expt. } & \multicolumn{2}{|l|}{ Prey } & \multirow[t]{2}{*}{ No. $1^{-1}$} & \multirow{2}{*}{$\begin{array}{c}\text { Dry wt } 1^{-1} \\
\left(\mu \mathrm{g} \mathrm{l}^{-1}\right)\end{array}$} & \multirow[t]{2}{*}{$\mu \mathrm{gC} 1^{-1}$} \\
\hline & & Type & Size $(\mathrm{mm})$ & & & \\
\hline \multirow[t]{20}{*}{ Filtering } & 4 & A. salina & 0.411 & 3.5 & 3.0 & - \\
\hline & 5 & A. salina & 0.530 & 1.3 & 2.0 & - \\
\hline & $7 \mathrm{~A}$ & A. salina & 0.600 & 3.2 & 7.0 & - \\
\hline & B & A. salina & 0.510 & 2.0 & 3.0 & - \\
\hline & 8 & A. salina & 0.448 & 3.1 & 4.0 & - \\
\hline & 11 & A. salina & 0.540 & 0.6 & 0.7 & - \\
\hline & & & & 1.0 & 1.3 & - \\
\hline & 12 & A. salina & 0.541 & 0.4 & 1.0 & - \\
\hline & 13 & B. plicatilis & 0.256 & 48.4 & 21.0 & 7.30 \\
\hline & $15 \mathrm{~A}$ & Synchaeta sp. & 0.129 & 555.5 & - & $-\cdot$ \\
\hline & B & A. salina & 0.544 & 3.1 & 5.0 & 0.94 \\
\hline & $\mathrm{C}$ & cysts & 0.224 & 68.0 & 102.0 & 43.35 \\
\hline & $16 \mathrm{~A}$ & A. salina & 0.711 & 3.9 & 11.0 & 2.09 \\
\hline & B & cysts & 0.225 & 59.9 & 90.0 & 36.91 \\
\hline & $17 \mathrm{~A}$ & Chaetoceros sp. & 0.093 & 1483280 & 80.3 & $24.90^{\circ}$ \\
\hline & B & Thallassionema sp. & 0.040 & 1597860 & 509.6 & $160.00^{\circ}$ \\
\hline & $18 \mathrm{E}$ & A. salina cysts & 0.226 & 1.9 & 3.0 & 1.28 \\
\hline & F & P. crassirostris & 0.484 & 0.6 & 2.0 & 0.24 \\
\hline & $19 \mathrm{I}$ & Chaetoceros sp. & 0.103 & 37503 & 4.68 & 1.38 \\
\hline & $\mathrm{J}$ & Chaetoceros sp. & 0.114 & 31524 & 3.93 & 1.16 \\
\hline \multirow[t]{14}{*}{ Biting } & 2 & C. carinatus & 2.490 & 0 & 0 & - \\
\hline & $3 \mathrm{~A}$ & $P$. africana & 1.160 & 0.3 & 11.0 & - \\
\hline & B & C. carinatus & 2.285 & 0 & 0 & - \\
\hline & 6 & P. hessi & 0.910 & 0.3 & 11.0 & - \\
\hline & 9 & A. salina & 7.110 & 0 & 0 & - \\
\hline & 10 & A. salina & 7.732 & 0 & 0 & - \\
\hline & $14 \mathrm{~A}$ & A. salina & 0.740 & 2.1 & 7.0 & 1.32 \\
\hline & B & A. salina & 0.902 & 1.0 & 5.0 & 0.94 \\
\hline & $\mathrm{C}$ & A. salina & 1.105 & 0 & 0 & 0 \\
\hline & D & A. salina & 1.413 & 0 & 0 & 0 \\
\hline & $18 \mathrm{~A}$ & A. salina & 0.725 & 4.3 & 14.0 & 2.64 \\
\hline & B & A. salina & 0.893 & 2.7 & 12.0 & 2.27 \\
\hline & C & A. salina & 1.071 & 0 & 0 & 0 \\
\hline & D & A. salina & 1.261 & 0 & 0 & 0 \\
\hline
\end{tabular}


filtering activity persisted at a low level throughout the $3 \mathrm{~h}$ trial. When presented with a Chaetoceros sp. monoculture containing 1 to 10 cell chains ranging in size from 11.4 to $114 \mu \mathrm{m}$ (Expt 19) the anchovy, which displayed filter feeding activity throughout the $5.5 \mathrm{~h}$ experiment, could not remove the 1 to 8 cell chains, but were able to filter the 9 and 10 cell chains at low rates (Table 3, Fig. 5). These results indicate that the minimum size of particle filterable by anchovy is between $93.0 \mu \mathrm{m}$ and $102.6 \mu \mathrm{m}$ maximum dimension.

Filtering trials using monocultures of Artemia salina nauplii produced higher clearance rates which generally increased with increasing particle size (Table 3 , Fig. 6). Prefeeding starvation times and initial food concentrations had little effect on feeding behaviour or clearance rates. During Expt 7, the fish were allowed to terminate feeding activity before more food was introduced to the tank.

Clearance rates for Artemia salina nauplii varied considerably between trials, although within any one experiment variation was minimal (Table3, Fig. 6). Changes in particle size do not account for these differences - the lowest clearance rate was obtained for the largest particle that the anchovy was observed to filter (Expt 16A). Behavioural variability, such as frequency and duration of filtering bouts, are the most likely causes of these disparities. Visual observations substantiate this, e.g. during Expt 16, the filtering bouts tended to be shorter and more sporadic than usual, with the fish also switching to particulate feeding for brief periods.

At the start of Expt 15, the introduction of Synchaeta sp. initiated feeding behaviour, but the anchovy lost interest and terminated filter feeding after $25 \mathrm{~min}$, without reducing the concentration of the rotifer in the water (Table 3, Fig. 7). These results are interesting, as the fish were unable to remove particles above the minimum threshold size of $102.6 \mu \mathrm{m}$ deduced from Expt 19. Also, the fish ceased feeding upon the rotifer after 25 min without causing a reduction in its concentration, yet during Expt 17, the fish continued to attempt, unsuccessfully, to filter the phytoplankton from the water until the trial was terminated. The clearance rate obtained for Brachionus plicatilis was only marginally greater than that for the 10 cell chains of Chaetoceros sp., although its measured maximum dimension was more than double that of the algae (Table 3).

Three trials were carried out to determine the effect of mixed size assemblages of prey on filter feeding clearance rates (Table 3, Figs. 7 and 9). During 2 of the trials only filterable foods were presented to the fish (Artemia salina nauplii and cysts; Expts 15 and 16), while in the third, both biteable and filterable foods were available (A. salina juveniles, cysts and Para- calanus crassirostris, Expt 18). In both the filtering trials, the clearance rates of the nauplii were lower than during experiments using $A$. salina monocultures. The cysts were cleared faster than would be expected for a particle of that size - the clearance rate obtained for
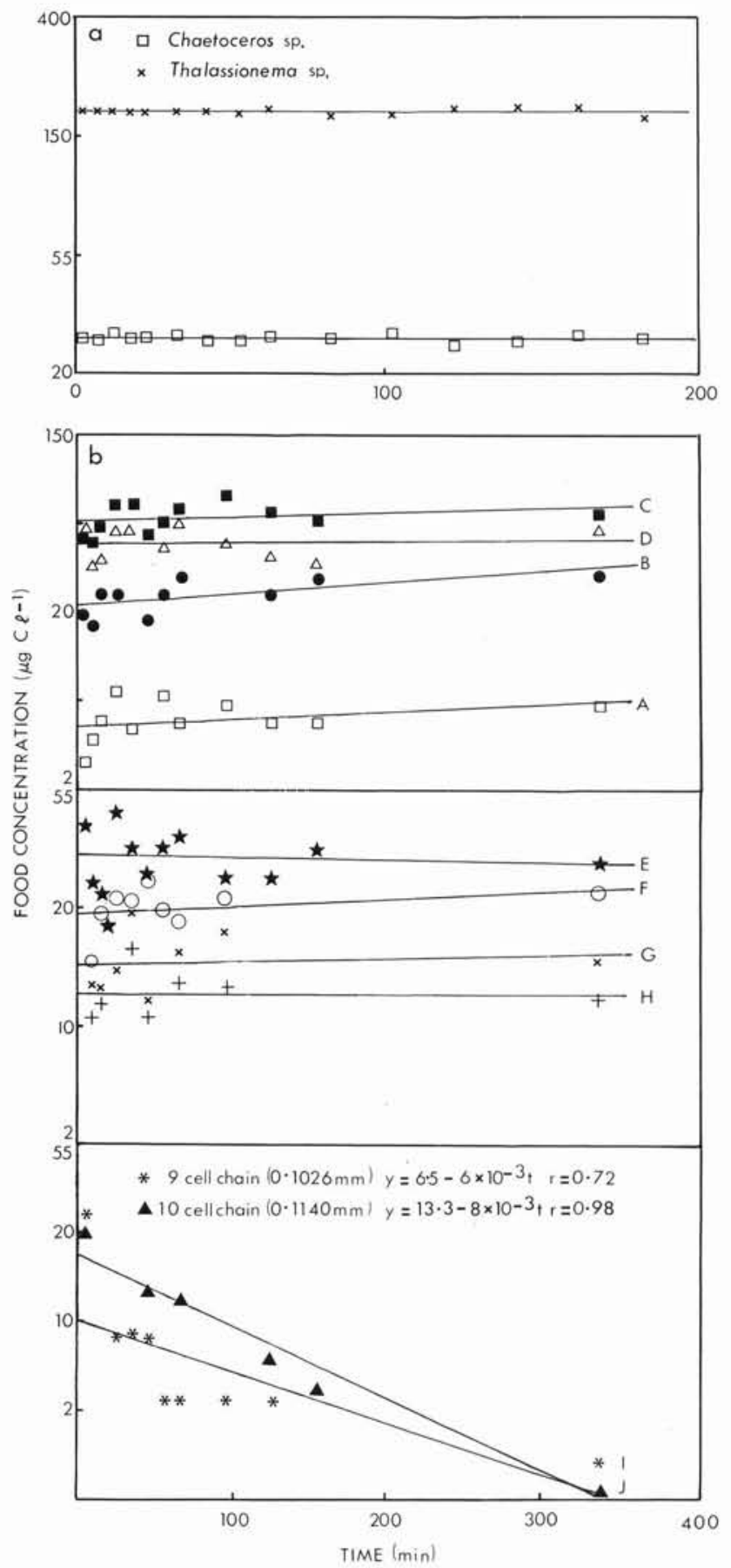

Fig. 5. Engraulis capensis. Filter feeding on phytoplankton. (a) Expt 17. Chaetoceros sp. 11 cell chains $(0.093 \mathrm{~mm})$ and single Thalassionema (0.040 mm) cells. (b) Expt 19. Chaetoceros sp. 1 to 10 cell chains $(0.0114$ to $0.114 \mathrm{~mm})$. A to $\mathrm{J}$ : increase in chain length from 1 to 10 cells 
Brachionus plicatilis was $0.2911 \mathrm{fish}^{-1} \mathrm{~min}^{-1}$ compared to 0.334 and $0.4021 \mathrm{fish}^{-1} \mathrm{~min}^{-1}$ for the cysts (Table 3 ). The rate obtained for the cysts during the biting experi- ment was even greater $\left(0.9261 \mathrm{fish}^{-1} \min ^{-1}\right)$. These increased rates may be partially attributed to the faster swimming speeds recorded during these trials relative

Table 3. Engraulis capensis feeding rates on various prey sizes. Standard deviations and $95 \%$ confidence limits indicated for swimming speeds (when film was used) and clearance rates (where residual mean square $>0.1$ ) respectively

\begin{tabular}{|c|c|c|c|c|c|}
\hline \multirow[t]{2}{*}{ Feeding mode } & \multirow[t]{2}{*}{ Expt. } & \multicolumn{2}{|c|}{ Prey } & \multirow{2}{*}{$\begin{array}{l}\text { Mean swimming } \\
\text { speed }\left(\mathrm{BL} \mathrm{s}^{-1}\right)\end{array}$} & \multirow{2}{*}{$\begin{array}{c}\text { Clearance rate, } F \\
\left(1 \mathrm{fish}^{-1} \mathrm{~min}^{-1}\right)\end{array}$} \\
\hline & & Type & Size $(\mathrm{mm})$ & & \\
\hline \multirow[t]{26}{*}{ Filter feeding } & $17 \mathrm{~A}$ & Thallassionema sp. & 0.040 & $1.598 \pm 0.330$ & - \\
\hline & $17 \mathrm{~B}$ & Chaetoceros sp. & 0.093 & & - \\
\hline & $19 \mathrm{~A}$ & Chaetoceros sp. & 0.0114 & $1.632 \pm 0.491$ & - \\
\hline & B & & 0.0228 & & - \\
\hline & $\mathrm{C}$ & & 0.0342 & & - \\
\hline & D & & 0.0456 & & - \\
\hline & E & & 0.0570 & & - \\
\hline & $\mathrm{F}$ & & 0.0684 & & - \\
\hline & G & & 0.0798 & & - \\
\hline & $\mathrm{H}$ & & 0.0912 & & - \\
\hline & I & & 0.1026 & & $0.194 \pm 0.112$ \\
\hline & $\mathrm{J}$ & & 0.1140 & & $0.258 \pm 0.073$ \\
\hline & $15 \mathrm{~A}$ & Synchaeta sp. & 0.129 & 1.883 & - \\
\hline & 13 & B. plicatilis & 0.256 & 1.630 & 0.291 \\
\hline & $15 \mathrm{C}$ & A. salina cysts & 0.224 & 2.100 & $\begin{array}{l}0.402 \pm 0.082 \\
(0.312)^{a}\end{array}$ \\
\hline & $16 \mathrm{~B}$ & & 0.225 & $2.059 \pm 0.826$ & $\begin{array}{c}0.334 \\
(0.264)^{\mathrm{a}}\end{array}$ \\
\hline & $18 \mathrm{E}$ & & 0.226 & $2.412 \pm 0.670$ & $\begin{array}{l}0.926 \pm 0.082 \\
(0.626)^{\mathrm{a}}\end{array}$ \\
\hline & $18 \mathrm{~F}$ & P. crassirostris & 0.484 & $2.412 \pm 0.670$ & $\begin{array}{l}0.609 \pm 0.088 \\
(0.495)^{\mathrm{b}}\end{array}$ \\
\hline & 4 & A. salina nauplii & 0.411 & 1.980 & $1.230 \pm 0.174$ \\
\hline & 5 & & 0.530 & 2.380 & $1.844 \pm 0.164$ \\
\hline & $7 \mathrm{~A}$ & & 0.600 & 2.500 & 2.305 \\
\hline & B & & 0.510 & 1.980 & 1.844 \\
\hline & 8 & & 0.448 & 1.860 & 1.383 \\
\hline & 12 & & 0.541 & 1.950 & $2.278 \pm 0.145$ \\
\hline & $15 \mathrm{~B}$ & & 0.544 & 2.100 & $0.871 \pm 0.066$ \\
\hline & $16 \mathrm{~A}$ & & 0.711 & $2.059 \pm 0.826$ & $0.668 \pm 0.041$ \\
\hline \multirow[t]{19}{*}{ Biting } & 6 & P. hesși & 0.910 & 2.680 & $2.920 \pm 0.519$ \\
\hline & $3 \mathrm{~A}$ & P. africana & 1.160 & 2.932 & $0.692 \pm 0.215$ \\
\hline & 2 & C. carinatus & 2.490 & 2.580 & $14.140 \pm 1.076$ \\
\hline & 3B & & 2.285 & 2.932 & $22.055 \pm 6.839$ \\
\hline & $14 \mathrm{~A}$ & $\begin{array}{l}\text { A. salina } \\
\text { juveniles }\end{array}$ & 0.740 & 2.798 & $\begin{array}{l}0.491 \\
3.009\end{array}$ \\
\hline & B & & 0.902 & & 0.702 \\
\hline & & & & & 4.841 \\
\hline & $\mathrm{C}$ & & 1.105 & & 1.341 \\
\hline & & & & & $4.252 \pm 0.132$ \\
\hline & D & & 1.413 & & $8.635 \pm 3.616$ \\
\hline & $18 \mathrm{~A}$ & & 0.725 & $2.412 \pm 0.670$ & 0.439 \\
\hline & & & & & $1.170 \pm 0.179$ \\
\hline & B & & 0.893 & & 0.780 \\
\hline & & & & & $2.828 \pm 0.219$ \\
\hline & $\mathrm{C}$ & & 1.071 & & 1.316 \\
\hline & & & & & 4.218 \\
\hline & D & & 1.261 & & $7.801 \pm 2.901$ \\
\hline & 9 & A. salina adults & 7.110 & 3.101 & $11.835 \pm 3.458$ \\
\hline & 10 & & 7.732 & 3.276 & $21.287 \pm 2.305$ \\
\hline
\end{tabular}


to the speed recorded for the $B$. plicatilis trial. The cyst clearance rates from the filtering trials become very similar to that for B. plicatilis when standardised against the swimming speed recorded during the latter trial (Table 3). However, the cyst clearance rate obtained from the biting trial remains greater, even after standardisation, probably due to the different feeding mode. In contrast the clearance rate for $P$. crassirostris was lower than expected. $P$. crassirostris is capable of burst swimming speeds of many $\mathrm{BL} \mathrm{s}^{-1}$, which is its main escape response. It is possible that during this trial, in which the anchovy were not direct- ing their feeding activity towards it, $P$. crassirostris avoided capture by using this response, thereby reducing the clearance rate relative to that obtained for the passive cysts.

\section{Particulate feeding}

The results of the biting trials are shown in Table 3 and Figs. 8 and 9. The clearance rates generally increased with particle size. The clearance rate obtained for Pseudodiaptomus hessi (Expt 6) may be an

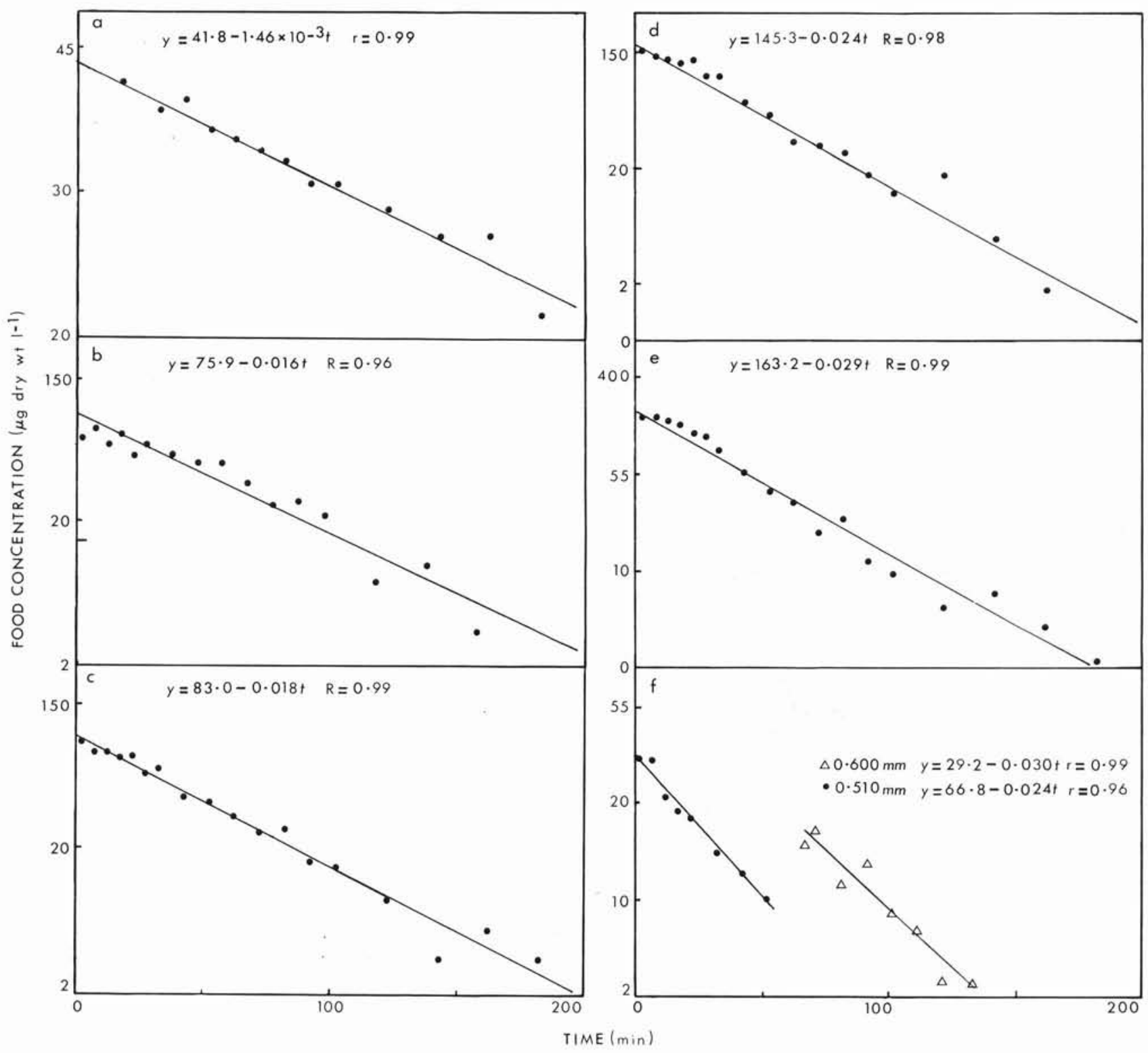

Fig. 6. Engraulis capensis. Filter feeding on monocultures of Brachionus plicatilis and Artemia salina. (a) Expt 13, B. plicatilis 0.256 mm; (b) Expt 4, A. salina $0.411 \mathrm{~mm}$; (c) Expt 8, A. salina 0.488 mm; (d) Expt 5, A. salina 0.530 mm; (e) Expt 12, A. salina 0.541 mm; (f) Expt 7, A. salina $0.600 \mathrm{~mm}$ and $0.510 \mathrm{~mm}$ 


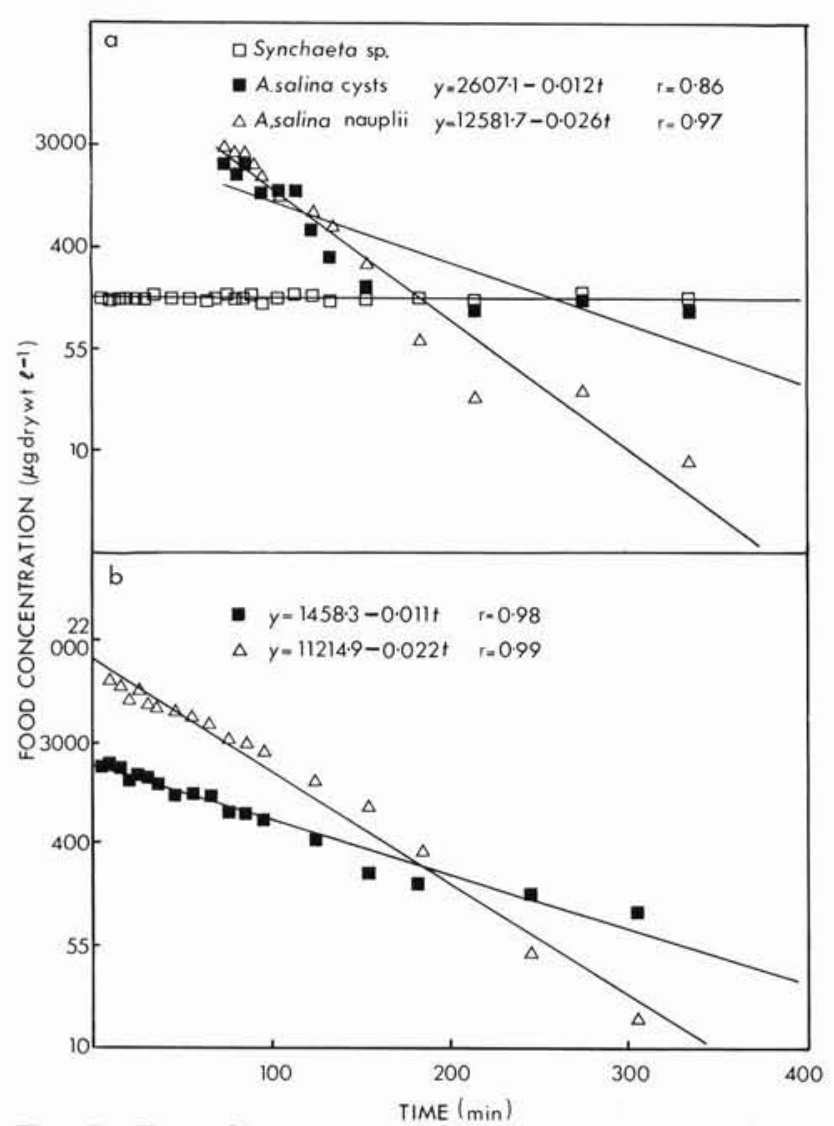

Fig. 7. Engraulis capensis. Filter teeding on mixed-size assemblages of microzooplankton

underestimate for particles of that size. This species tended to be situated near or on surfaces during culture, thus making it less accessible to the fish. The rates obtained for Artemia salina adults, on the other hand, may be overestimates, since $A$. salina does not possess the well-developed escape response of similar sized zooplankters which make up part of the natural diet of Engraulis capensis, such as the euphausiid Euphausia lucens. E. lucens was not used as an experimental food, because the majority of the prey settled to the bottom immediately after introduction. This behaviour is typical of $E$. lucens maintained in the laboratory (Pillar pers. comm.).

When mixed-size assemblages of food were offered to the anchovy, the clearance rates of the largest foods were high and similar to expected values, while those of the smaller particles were initially only ca $30 \%$ of the expected values, but increased after the complete removal of the largest food available (Table 3, Fig. 9). These results indicate that the fish direct their attention towards the largest available food, ignoring the smaller items and suppressing their clearance rates until the preferred prey are removed. There was a lag period of 40 to $60 \mathrm{~min}$ between the erradication of the largest food available and the increase in the clear- ance rates of the smaller particles (Fig. 9). Presumably this was due to the fish continuing to search for their preferred prey, whilst adjusting their search image towards the smaller prey. There were no obvious changes in feeding behaviour during the experiments. After the removal of the largest prey, the clearance rates of the remaining food sizes were closer to expected values (Table 3 ).

Clearance rates of similar-sized particles were more variable during biting trials than during filtering trials (Table 3). The clearance rates of Calanoides carinatus and Artemia salina adults varied by 56 and $80 \%$ respectively in consecutive experiments (Table 3 ). Changes in swimming speed, prey size and concentration do not account for these differences, and, except for the light regime during Expt 10, experimental conditions were identical in all respects. The disparities may be due to unquantified differences in feeding behaviour caused by factors such as disturbance, state of hunger or feeding history. One interesting fact is that in both cases clearance rates were higher during the second experiment. Both pairs of trials were run on consecutive days, with no feeding taking place in between. It is possible that a search image developed during the first experiment persisted and enhanced the rate of capture during the following trial. Observations during the collection of the reactive distance data indicated that the anchovy formed a search image for a prey type that was offered several times in succession, but there are no data about the length of time such an image persists.

\section{DISCUSSION}

The types of feeding behaviour described for Engraulis capensis are similar in many respects to those recorded for other intermediate microphagists such as E. mordax (Leong \& O'Connell 1969, O'Connell 1972, Hunter \& Dorr 1982), Scomber japonicus (O'Connell \& Zweifel 1972), Alosa pseudoharengus (Janssen 1976, 1978), Dorosoma petenense (Holanov \& Tash 1978) and Clupea harengus (Gibson \& Ezzi 1985). The major difference in the feeding behaviour of $E$. capensis was that they did not filter feed on large particles when present in high densities nor switch to biting when the density was reduced below a threshold concentration as described for other planktivores (O'Connell 1972, O'Connell \& Zweifel 1972, Hunter \& Dorr 1982, Gibson \& Ezzi 1985). During only 1 experiment were the 2 feeding modes observed simultaneously (Expt 16), when the fish commenced filter feeding and later, when food densities were reduced, alternated between filtering and biting. The switch from filtering to biting with decreasing prey density may 

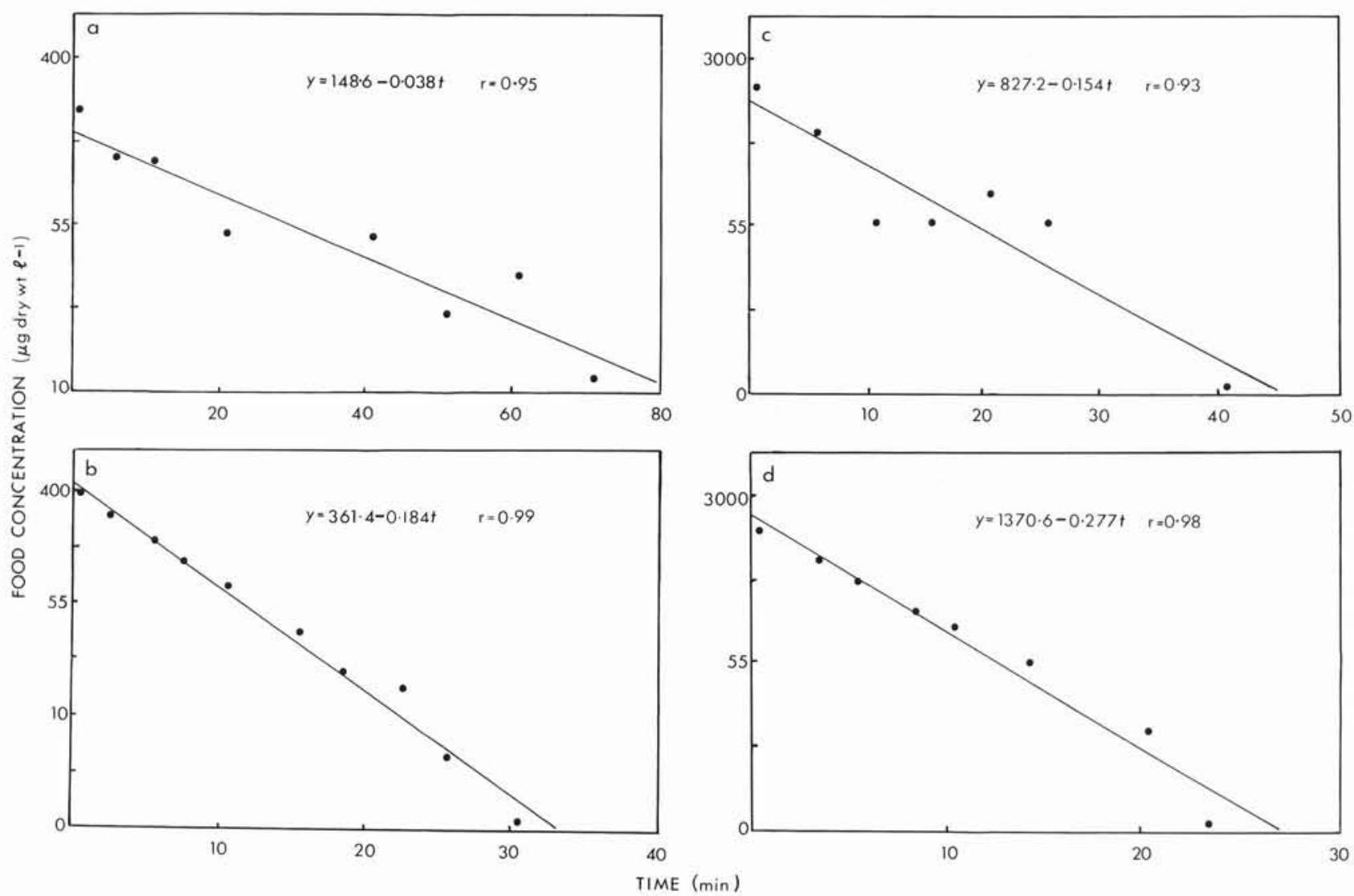

Fig. 8. Engraulis capensis. Particulate feeding on monocultures of mesozooplankton. (a) Expt 6, Pseudodiaptomus hessi 0.910 mm, (b) Expt 2, Calanoides carinatus $2.490 \mathrm{~mm}$; (c) Expt 9, Artemia salina $7.110 \mathrm{~mm}$; (d) Expt 10, A. salina $7.732 \mathrm{~mm}$

only occur in E. capensis over a very limited size range approximating the threshold size of 0.710 to $0.720 \mathrm{~mm}$ associated with the observed switch in feeding behaviour from filtering to biting. Within this range the energy gain versus expenditure to acquire a particle at any concentration may dictate the feeding mode employed. Gibson \& Ezzi's (1985) conclusion that $C$. harengus switched from filter feeding to biting when prey density was reduced below a threshold level were based on experiments using 1 prey size (Artemia salina nauplii). The results of the present study, using a wide range of prey sizes and densities, indicate that their work might not be representative of the feeding repertoire of $C$. harengus, but described a special case where the prey used fell within a narrow band of sizes. In this situation the density and size would interact to determine the feeding behaviour of the fish. O'Connell (1972) stated that biting replaced filtering behaviour when E. mordax was presented with a mixture of $A$. salina nauplii and adults. Filter feeding only increased in intensity after removal of adults. This observation is in agreement with the findings of the present study, during which no active filter feeding occurred when the anchovy were presented with a wide range of food sizes (Expt 18).

The loose aggregations observed during biting activity have been noted for other planktivores. Hobson (1968) stated that the flat iron herring Harengula thrissina fed on midwater crustaceans while in scattered layers. Longhurst (1971) and O'Connell (1972) noted that Engraulis mordax schools were more diffuse when feeding on large particles, and $\mathrm{O}^{\prime}$ Connell (1972) and Eggers (1976) stated that this increased the predator-prey encounter rate. This behaviour is also advantageous since it decreases the overlap of the visual fields of the fish (Eggers 1976, E. G. Durbin pers. comm.) and allows all the fish to feed effectively upon the available prey. If the fish remained in a tight school the potential volume searched would be considerably reduced. The fish at the leading edge could also remove most of the food from the water and thereby reduce the following fishes' consumption rate. Similarly, the broadening of the school's leading edge during filtering increases the predators' exposure to the prey and reduces competition between feeding fish in a school. Similar shoal configurations have been 

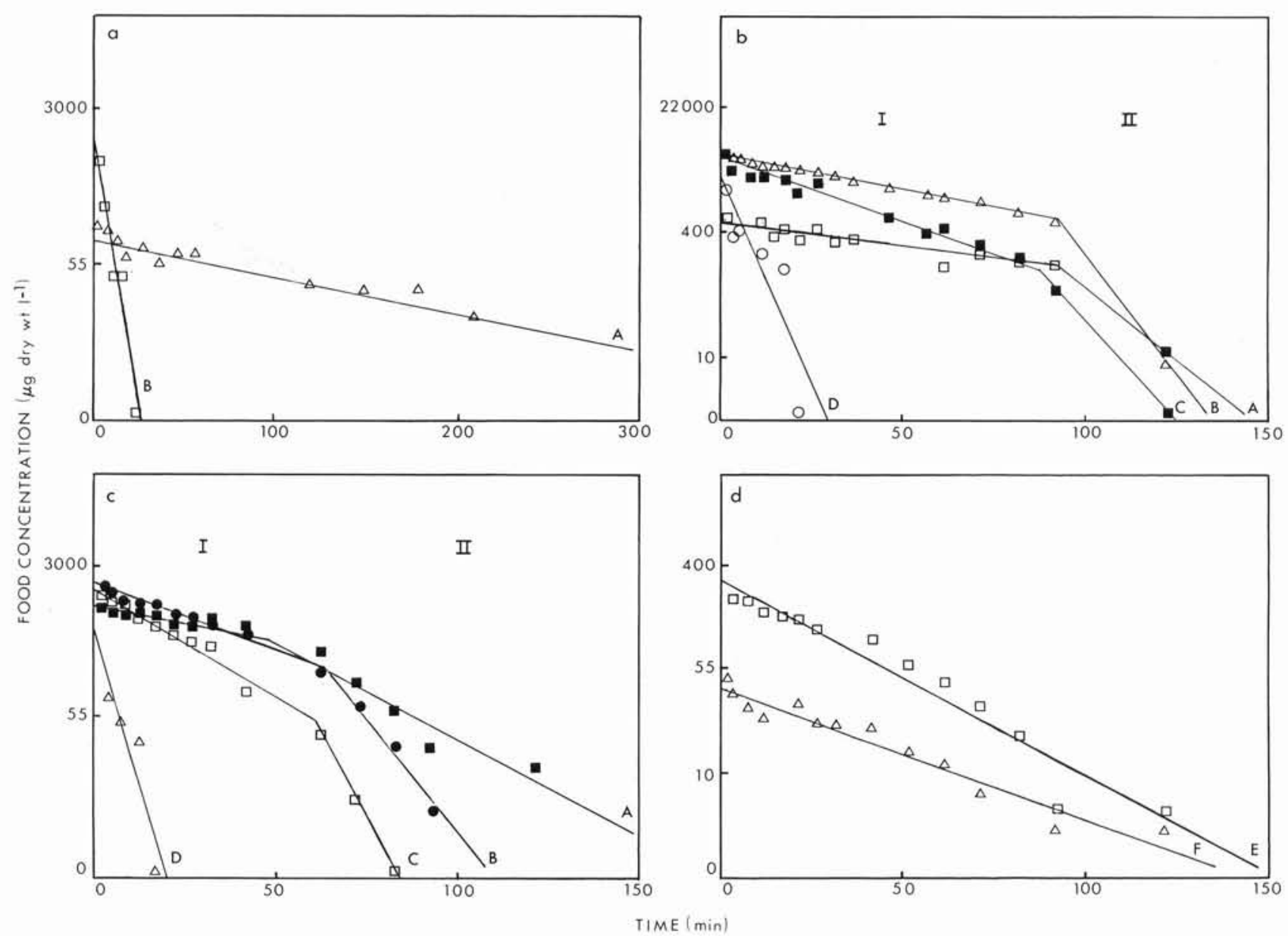

Fig. 9. Engraulis capensis. Particulate feeding on mixed-size assemblages of mesozooplankton
(a) Expt 3, Paracartia africana $1.160 \mathrm{~mm}$ (A) and Calanoides carinatus $2.285 \mathrm{~mm}$ (B)
(A) $y=81.5-0.009 t, \quad r=0.87$
(B) $y=499.2-0.287 t, \quad r=0.96$
(b) Expt 14, Artemia salina juveniles
(A) $0.740 \mathrm{~mm}$
(B) $0.902 \mathrm{~mm}$
(C) $1.105 \mathrm{~mm}$
(D) $1.413 \mathrm{~mm}$
$y=403.8-0.015 t, \quad r=0.92$
$y=3013.9-0.041 t, \quad r=0.98$
$y=3351.0-0.022 t, \quad r=1.00$
$y=1068.5-0.264 t, \quad r=0.87$
(c) Expt 18, A. salina juveniles
$\begin{array}{lll}\text { I } & \\ \text { (A) } 0.725 \mathrm{~mm} & y=813.2-0.018 t, & r=0.98 \\ \text { (B) } 0.893 \mathrm{~mm} & y=1365.1-0.032 t, & r=0.98 \\ \text { (C) } 1.071 \mathrm{~mm} & y=1127.8-0.054 t, & r=0.98 \\ \text { (D) } 1.261 \mathrm{~mm} & y=231.4-0.320 t, & r=0.95\end{array}$
II
$y=4.108 \mathrm{e} 5-0.092 t, \quad r=1.00$
$y=2.687 \mathrm{e} 8-0.148 t, \quad r=1.00$
$y=5.769 \mathrm{e} 6-0.130 t, \quad r=1.00$
(d) Expt 18, A. salina cysts $0.226 \mathrm{~mm}$ (E) and Paracalanus crassirostris $0.484 \mathrm{~mm}$ (F)
(E) $y=243.7-0.038 t, \quad r=0.97$
(F) $y=30.3-0.025 t, \quad r=0.97$

observed for feeding E. mordax in the wild (Koslow 1981).

The density and biomass threshold concentrations required to initiate filter feeding in Engraulis capensis were inversely related to prey size. Durbin \& Durbin (1975) drew similar conclusions for Brevoortia tyrannus, but Hunter \& Dorr (1982) found that while the former threshold was negatively correlated, the latter was positively correlated to prey size in E. mordax. The levels of food required to initiate filtering were lower than those required by B. tyrannus (Durbin \& Durbin 1975), but greater than those for E. mordax (Hunter \& 
Dorr 1982). These data may reflect a progression in adaptation to unstable environments with patchy food distributions from $B$. tyrannus, which inhabits eutrophic coastal areas through E. capensis to E. mordax which occupy pulse and belt upwelling systems. However, one would expect the positions of E. capensis and E. mordax to be reversed. The Southern Benguela is less stable than the Southern Californian system, which is downstream of the Central Californian and Oregon upwelling areas and benefits from their exported production as well as that from temperate offshore waters advected southwards by the California Current (Shelton 1986). This disparity is due to the different criteria used to stipulate the threshold concentrations during the 2 studies. During the present study at least $50 \%$ of the school had to be observed to be feeding, while Hunter \& Dorr (1982) only sought a significant difference between the initial and final concentrations of food in the tank over a 9 or 18 min period. The incidence of filtering was less than $50 \%$ in all but one of the Artemia salina experiments and less than $10 \%$ during the Gymnodinium sp. trials. The latter incidences of filtering activity would have been classified as gaping activity during the present study. The threshold concentrations determined by Hunter \& Dorr (1982) would have been considerably higher if a $50 \%$ incidence of filtering had been stipulated. The thresholds determined by Hunter \& Dorr for anchovy eggs, on the other hand, are spuriously high since the anchovy will particulate feed upon eggs at much lower densities.

The food densities required to initiate filter feeding by Engraulis capensis were generally exceeded in the field (Table4). This fact is, however, of debatable ecological significance since the presence of prey which stimulate biting will have the dual effects of suppressing directed filtering activity, but simultaneously increasing the incidental consumption of smaller particles. Field evidence for the incidental consumption of phytoplankton and microzooplankton has been presented for E. capensis (James 1987) and other planktivores (Parr 1930, Cushing 1978).

The replacement of filtering by biting when mixedsize assemblages of food are available suggests that filtering may only be of importance when there are either no large particles present in the water or when feeding activity is low. James (1987) noted that filtering activity in Engraulis capensis was highest when overall trophic activity was low. O'Connell (1972) and Angelescu (1982) made similar observations for Engraulis mordax and E. anchoita respectively. However, food acquisition by filtering must not be underestimated. Experimental and field data (James 1987) demonstrate that the incidental intake of small particles during particulate feeding can be substantial.
The termination threshold levels found during this study may similarly be of limited value and little more than artefacts of the experimental design since in the field the fish will continue to consume small prey below the laboratory determined threshold levels as long as there are large particles $(>0.720 \mathrm{~mm})$ present which stimulate particulate feeding.

The disparity between the minimum size for microzooplankton ( 0.129 to $0.256 \mathrm{~mm}$ ) and phytoplankton ( 0.093 to $0.1026 \mathrm{~mm}$ ) that could be filtered from the water is of interest. Chaetoceros sp. possess strong elongate setae which increase the apparent dimensions of the cell considerably, depending on the species (Cupp 1943). The similarity between the clearance rate of the 10 cell chains of the Chaetoceros sp. monoculture and that of Brachionus plicatilis suggest that the setae more than doubled the size of the algal chains. It can therefore be deduced that the minimum size the anchovy can filter has a maximum dimension of ca 0.200 to $0.250 \mathrm{~mm}$ rather that $0.100 \mathrm{~mm}$. The coarseness of the filtering mechanism will preclude the anchovy from utilising a large proportion of the phytoplankton standing stock in the Southern Benguela (Table 4). Only large dinoflagellates and diatom cells and chains, or species with long setae will be available to Engraulis capensis, and even these can only be filtered with limited success (Table 3 ). The smaller flagellate and diatom populations will be inaccessible to the anchovy. These findings could imply resource partitioning between anchovy and its major food sources - herbivorous and omnivorous zooplankton. However, King \& Macleod (1976) and James (1987) found many food items less than $0.200 \mathrm{~mm}$ in the stomachs of E. capensis from the south and west coasts of South Africa. The pore sizes may vary with the degree of mouth opening; becoming smaller when the mouth closes after a biting attack and pushes the water through the gill rakers, thus trapping smaller particles. The coarseness of the filtering mechanism observed during directed filtering suggests that this feeding mode may only be used in the wild to prey upon aggregations of microzooplankton.

Filtering rates of Engraulis capensis feeding on Artemia salina are of the same order as those of $E$. mordax and Brevoortia tyrannus (corrected for the differences in swimming speed and mouth area between the 2 species) and are greater than those of Clupea harengus (Table5). Clearance rates of small particles are greater for $B$. tyrannus, while that for the larger Acartia tonsa is less than the rate of an equivalent sized particle consumed by E. capensis. This illustrates both the finer filtering mechanism of the menhaden and the switch from filtering to biting by the anchovy. There is no levelling off of the filtering rate of the anchovy with increasing particle size as found for 
Table 4. Biomass of potentially available food for Engraulis capensis in the Southern Benguela Region. Data derived from recent plankton surveys. The 0 to $0.2 \mathrm{~mm}$ and 0.2 to $0.5 \mathrm{~mm}$ size categories contain the bulk of the phytoplankton and microzooplankton biomasses respectively

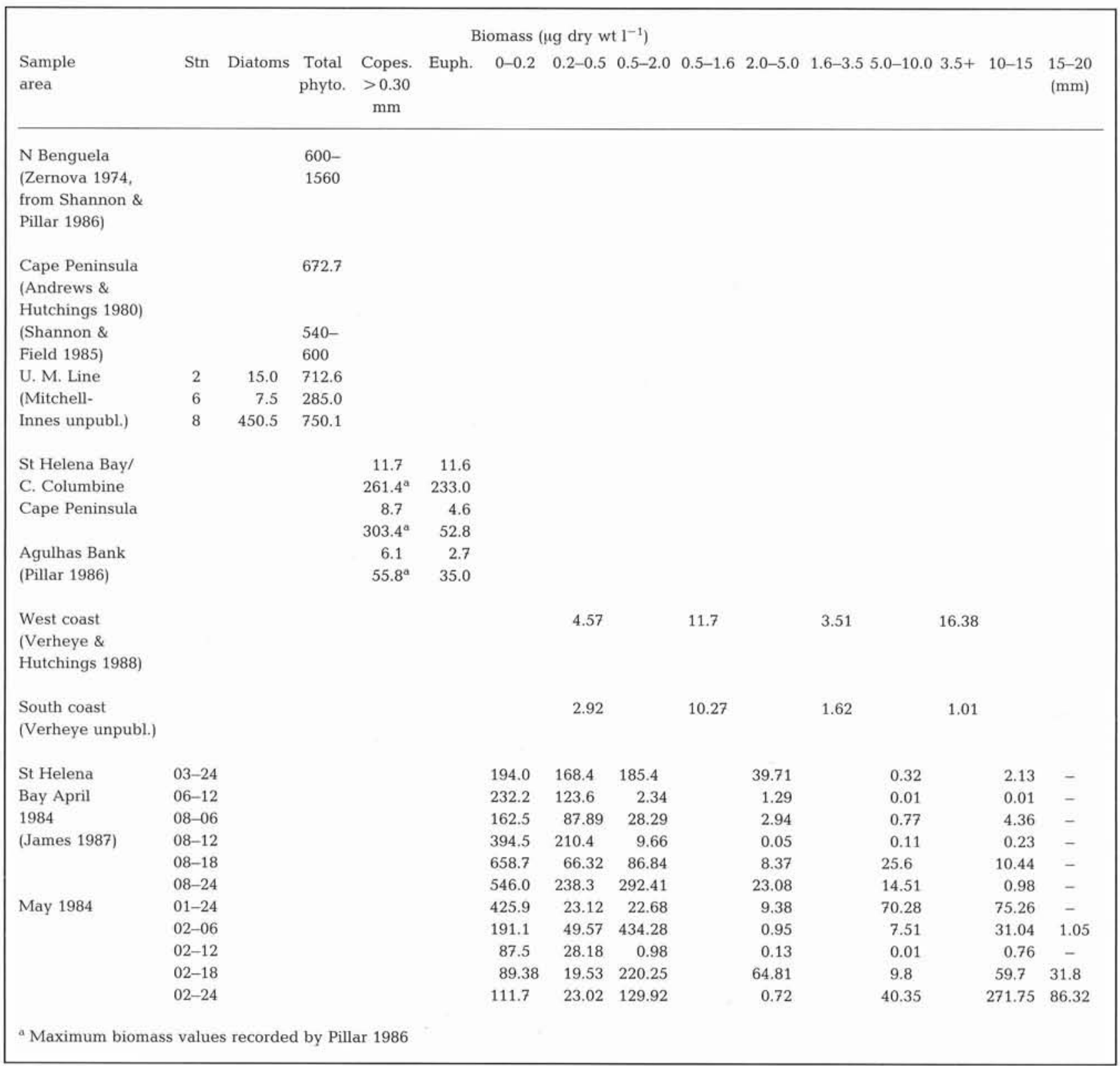

the menhaden (Durbin \& Durbin 1975). The anchovy's rates continue to increase until feeding behaviour switches to biting.

Clearance rate data are adequately described by a Gompertz model (Fig. 10), with no discontinuity between filtering and biting rates. It was considered appropriate to treat all data en masse because of the similarities in their functional relationships (Figs. 5 to 9). Clearance rate increases rapidly with increasing prey size between lower and upper thresholds of 0.250 and $2.500 \mathrm{~mm}$ respectively, after which it attains a maximum value (Fig. 10). James (1987) found that the bulk of the anchovy's diet was between 1.0 and $15.0 \mathrm{~mm}$, indicating that the anchovy generally particulate-feeds at high or maximal rates. The rapid biting clearance rate under low light conditions agrees with the findings of James (1987) who observed that the peak feeding times of Engraulis capensis were between dusk and midnight on the west, and midnight to midmorning on the south coasts. O'Connell (1963) demonstrated that the eyes of E. mordax were well adapted to low-light vision. Hunter \& Nicoll (1984) 


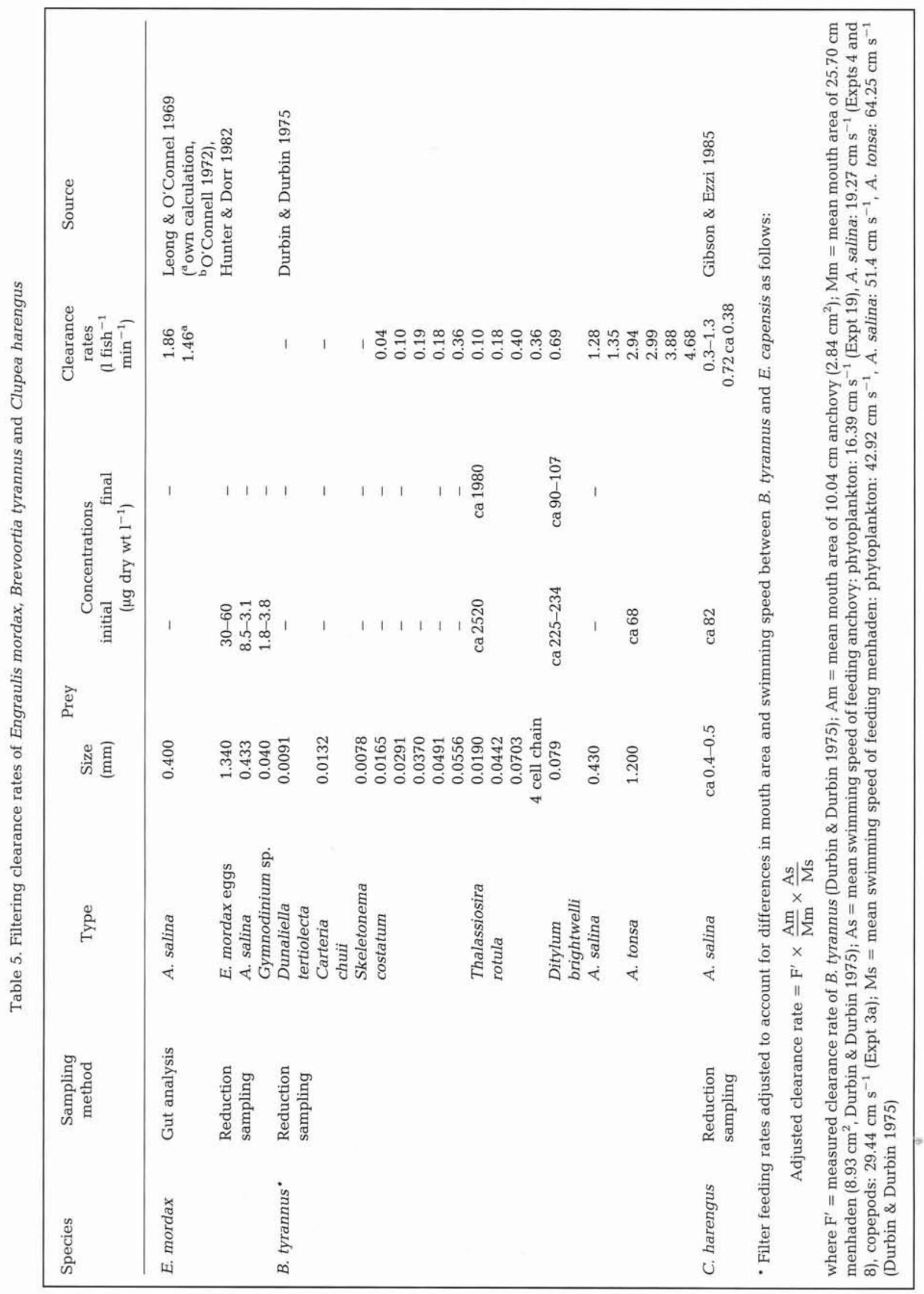


calculated that there was enough light at $30 \mathrm{~m}$ depth in chlorophyll-poor water $\left(0.24 \mathrm{mg} \mathrm{Chl} \mathrm{a} \mathrm{m}{ }^{-3}\right)$ on a starlit night to allow the visual cues required for schooling and spawning in E. mordax to operate. Hunter (1968) stated that Trachurus symmetricus obtained $50 \%$ of its ration during low-light conditions similar to that of surface coastal waters at night under a full moon. It is also possible that another sensory organ, such as the lateral line, plays an important role in prey location in low-light conditions. However, the indication that vision and prey location are not important to the anchovies' feeding rates are an artefact of the experimental conditions. In the field, where light levels are lower and the prey more heterogeneously distributed in relation to the fish than during experiments, these factors will become important.

The data clearly illustrate the anchovies' ability to select food on the basis of size, as reported during field studies for Engraulis mordax (Koslow 1981) and E. capensis (James 1987). This selective feeding on larger prey items through the suppression of the clearance rates of smaller particle sizes, and the fact that clearance rates are maximal over most of the range of prey sizes could have important ramifications in the field. The predators' impact would be to select for plankton communities composed of smaller species. Such an effect has been observed in both marine (Durbin \& Durbin 1975, Koslow 1981, Hunter \& Dorr 1982) and freshwater systems (Warshaw 1972, Drenner \& Des Noyelles 1982). However, these data also indicate that anchovy can readily re-direct its feeding activity towards smaller items. This finding is similar to field observations of the selective feeding behaviour of $E$. mordax (Koslow 1981). He observed that the northern anchovy was capable of removing 95 to $100 \%$ of the largest prey available over a 100 -fold range in prey size. James (1987) presented field data which indicate that consumption of smaller prey was suppressed when

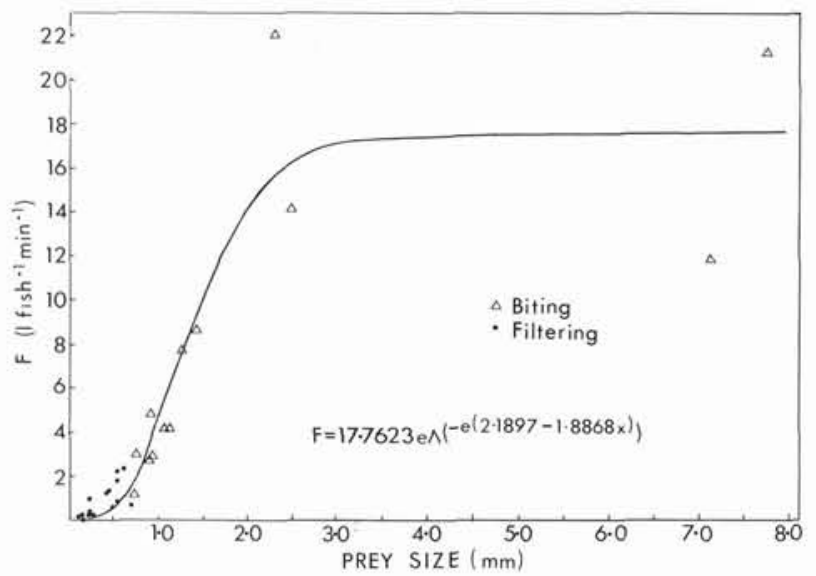

Fig. 10. Engraulis capensis. Clearance rates $\left[F\left(1 \mathrm{fish}^{-1} \mathrm{~min}^{-1}\right)\right]$ as a function of prey size ( $\mathrm{mm})$ the fish preferentially fed upon larger particles. However, the rate of consumption of filterable items - considered as an incidental catch when the fish pursued larger prey - increased when these preferred prey were scarce or absent. This flexible and highly opportunistic feeding behaviour is advantageous in an unstable environment such as the Southern Benguela. The anchovy can maximise their intake of large particles, which tend to be patchy (Alldredge et al. 1984, Nicol et al. 1987), while continuing to take advantage of the smaller, more abundant and homogenously distributed particles.

Ingestion rates estimated from recent biomass data (Table 6) demonstrate that the anchovy could fulfill its daily requirement (ca $10 \%$ body weight $\mathrm{d}^{-1}$, Shannon \& Field 1985) by particulate and associated incidental filter feeding in the Southern Benguela. These data also illustrate the requirement for small-scale intensive sampling strategies rather than large-scale plankton surveys (Pillar 1986, Verheye \& Hutchings 1988, Verheye unpubl.) for the purpose of investigating the trophic ecology of planktivorous fishes. Most of the available data are integrated over large vertical and horizontal ranges. Verheye \& Hutchings (1988) and Verheye (unpubl.) provided more suitable data by vertically stratifying their samples over several tens of metres. However, even this does not account for the scale of patchiness of plankton which the fish can perceive, react to and utilise. Only more coordinated sampling strategies, e.g. those of Koslow (1981) and James (1987), can provide such information. It must also be realised that biomass and standing stock estimates from plankton surveys only represent the survivors of fish predation. The crucial point, both in terms of attainment of daily ration and the effect on prey communities, is the proportion of the production removed by the fish.

If peak biomass estimates of Pillar (1986) - presuming that aggregations of prey were sampled (Pillar pers. comm.) - are used to calculate ingestion rates the values are similar to those estimated using the data of James (1987) ( 0.8 to $5.0 \mathrm{~h}$ for the former, 0.6 to $5.7 \mathrm{~h}$ for the latter values, Table 6 ). The time required to consume $10 \%$ body weight is greater on the south than on the west coast, thus explaining the extended feeding period in the former area (James 1987).

O'Connell (1972) suggested that filtering provided a continuous intake of food for Engraulis mordax, with biting supplying the remainder of the daily ration. This is energetically uneconomic due to the high energy output required to sustain filtering compared to normal swimming (James \& Probyn unpubl.). It is energetically more advantageous for the fish to employ biting, which is less expensive (James \& Probyn unpubl.) and provides a higher return. However, there are large bio- 


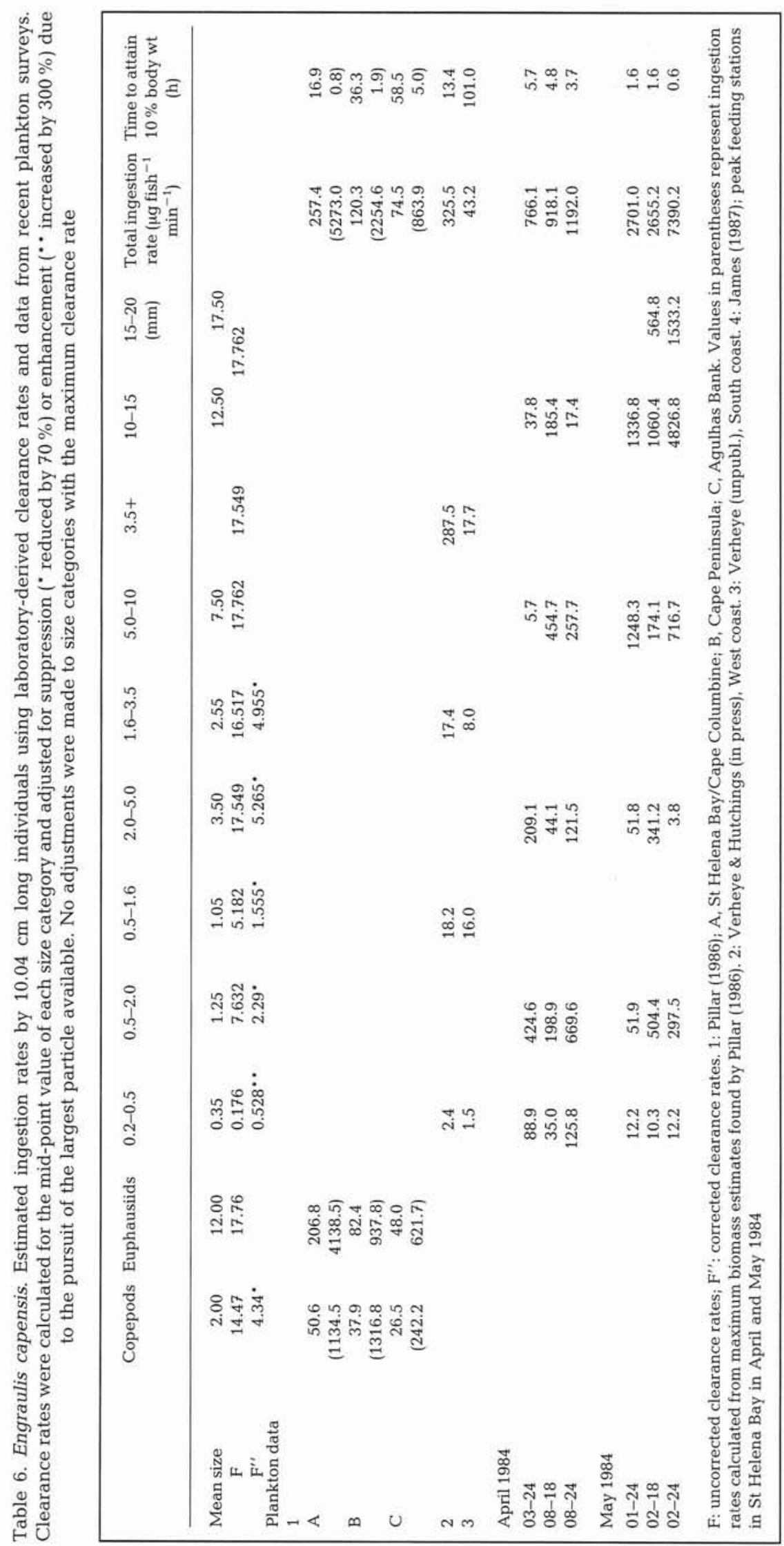


masses of phytoplankton and microplankton available for consumption in the Southern Benguela. It would appear that E. capensis has taken account of these energetic and trophic considerations by refining its feeding behaviour to the extent that, although it particulate feeds mainly upon mesozooplankton, it can simultaneously collect phyto- and micro-zooplankton using its gill raker mechanism, thus minimising energy expenditure and maximising gain.

\section{SUMMARY}

(1) This laboratory work corroborates findings of an earlier field study investigating the trophic ecology of Engraulis capensis (James 1987). (2) Schooling behaviour displayed by Engraulis capensis during feeding enhances its feeding rate. (3) E. capensis acquire the bulk of their food by size-selective particulate feeding on items $>0.720 \mathrm{~mm}$, selecting for the largest available particle. This selection is achieved through suppression of the clearance rates of smaller particles. (3) Anchovy feed at maximum rate over most of the range of their trophic size spectrum. (4) The feeding behaviour of $E$. capensis is very flexible, allowing a rapid switch from filtering to biting, and a redirection of the size-selective feeding to smaller items after removal of the largest available prey. (5) Anchovy have refined their feeding behaviour such that they can simultaneously take advantage of the mesozooplankton, towards which they direct most of their feeding activity, and portions of the available phyto- and microzooplankton.

Acknowledgements. We thank Dr R. N. Gibson (Scottish Marine Biological Association), Professor E. G. Durbin (Univ. of Rhode Island Graduate School of Oceanography), Drs L. Hutchings, M. J. Armstrong, Mrs D. A. Armstrong, Mr G. C. Pitcher (Sea Fisheries Research Institute), and Dr T. A. Probyn (University of Cape Town) for constructive criticisms of our manuscript. Mr S. C. Pillar (SFRI), Ms P. A. Wickens and $\mathrm{Mr}$ C. Villacastin-Herrero (UCT) assisted with the statistical analyses. Financial assistance from the Sea Fisheries Research Fund for the capture and transfer of wild pelagic fish is gratefully acknowledged. This work is being submitted in partial fulfillment of the requirement of a Ph.D. at the University of Cape Town.

\section{LITERATURE CITED}

Alldredge, A. L., Robison, B. H., Fleminger, A., Torres, J. J., King, J. M., Hamner, W. M. (1984). Direct sampling and in situ observation of a persistent copepod aggregation in the mesopelagic zone of the Santa Barbara Basin. Mar. Biol. 80: $75-81$

Andrews, W. R. H., Hutchings, L. (1980). Upwelling in the southern Benguela Current. Prog. Oceanogr. 9: 1-81

Angelescu, V. (1982). Ecologia trofica de la anchoita del mar
Argentino (Engraulidae: Engraulis anchoita). Parte II. Alimentacion, comportamiento y relaciones troficas en el ecosistema. Contribucion Instituto Nacional de Investigacion y Desarrollo Pesquero. 409: 1-83. (Translated from Spanish)

Cupp, E. E. (1943). Marine plankton diatoms of the west coast of North America. Bull. Scripps Instn Oceanogr. 5 (1): 1-237

Cushing, D. H. (1978). Upper trophic levels in upwelling areas. In: Boje, R., Tomczak, M. (eds.) Upwelling ecosystems. Springer-Verlag, New York, p. 101-110

Drenner, R. W., De Noyelles, F. Jr (1982). Selective impact of filter feeding gizzard shad on zooplankton community structure. Limnol. Oceanogr. 27: 965-968

Durbin, A. G., Durbin, E. G. (1975). Grazing rates of the Atlantic menhaden Brevoortia tyrannus as a function of particle size and concentration. Mar. Biol. 33: 265-277

Eggers, D. M. (1976). Theoretical effect of schooling by planktivorous fish predators on the rate of prey consumption. Fish. Res. Bd Can. 33: 1964-1971

Frost, B. W. (1972). Effects of size and concentration of food particles on the feeding behaviour of the marine planktonic copepod Calanus pacificus. Limnol. Oceanogr. 17: 805-815

Gibson, R. N., Ezzi, I. A. (1985). Effect of particle concentration on filter- and particulate feeding in the herring Clupea harengus. Mar. Biol. 88: 109-116

Harvey, H. W. (1937). Note on selective feeding by Calanus. J. mar. biol. Ass. U.K. 22: 97-100

Hasle, G. R. (1978). The inverted microscope method. In: Sournia, A. (ed.) Phytoplankton manual. UNESCO Monographs on Oceanographic Methodology, 6: 88-96

Hobson, E. S. (1968). Predatory behaviour of some shore fishes in the Gulf of California. U.S. Fish. Wildl. Serv. Res. Rep. 73: $1-92$

Holanov, S. H., Tash, J. C. (1978). Particulate and filter feeding in threadfin shad, Dorosoma petenense, at different light intensities. J. Fish Biol. 13: 619-625

Holling, C. S. (1966). The functional response of invertebrate predators to prey density. Mem. Entomol. Soc. Can. 45: $1-86$

Hunter, J. R. (1968). Effects of light on schooling and feeding of jack mackerel, Trachurus symmetricus. J. Fish. Res. Bd Can. 25: 393-407

Hunter, J. R., Dorr, H. (1982). Thresholds for filter feeding in northern anchovy, Engraulis mordax. Rep. Calif. coop. oceanic Fish. Invest. 13: 198-204

Hunter, J. R., Nicoll, R. (1984). Visual thresholds for schooling in northern anchovy Engraulis mordax. Fish. Bull. U.S. 83: 235-242

James, A. G. (1987). Feeding ecology, diet and field based studies on feeding selectivity of the Cape anchovy, Engraulis capensis Gilchrist. In: Payne, A. I. L., Gulland, J. A., Brink, K. H. (eds.) The Benguela and comparable ecosystems. S. Afr. J. mar. Sci. 5: 673-692

James, A. G. (1988). Ecology of the Cape Anchovy, Engraulis capensis in the southern Benguela ecosystem. Ph. D. thesis, University of Cape Town

James, A. G., Hutchings, L. A., Brownell, C. L., Horstman, D. (1988). Methods of capture and transfer to the laboratory of wild pelagic fish. S. Afr. J. mar. Sci, 6: 17-21

Janssen, J. (1976). Feeding modes and prey size selection in the Alewife (Alosa pseudoharengus). J. Fish. Res, Bd Can. 33: $1972-1975$

Janssen, J. (1978). Feeding-behaviour repertoire of the Alewife, Alosa pseudoharengus, and the Ciscoes, Coregonus hoyi and C. artedii. J. Fish. Res. Bd Can. 35: 249-253 
King, D. P. F., Macleod, P. R. (1976). Comparison of the food and the filtering mechanism of pilchard Sardinops ocellata and anchovy Engraulis capensis off South West Africa, 1971-1972. Investl Rep. Sea Fish. Brch S. Afr. 111: 1-29

Koslow, J. A. (1981). Feeding selectivity of schools of northern anchovy, Engraulis mordax, in the Southern California Bight. Fish. Bull., Wash. 79: 131-142

Leong, R. J. H., O'Connell, C. P. (1969). A laboratory study of particulate and filter feeding of the northern anchovy (Engraulis mordax). J. Fish. Res. Bd Can. 26: 557-582

Longhurst, A. R. (1971). The clupeoid resources of tropical seas. In: Barnes, H. (ed.) Oceanogr. Mar. Biol. Ann. Rev. 9, Allen and Unwin, London, p. 349-385

Marin, V., Huntley, M. E., Frost, B. (1986). Measuring feeding rates of pelagic herbivores: analysis of experimental design and methods. Mar. Biol. 93: 49-58

Nicol, S., James, A. (G.), Pitcher, G. (C.) (1987). A first record of daytime surface swarming by Euphausia lucens in the Southern Benguela region. Mar. Biol. 94: 7-10

O'Connell, C. P. (1963). The structure of the eye of Sardinops caerulea, Engraulis mordax, and four other pelagic marine teleosts. J. Morphol. 113: 287-330

O'Connell, C. P. (1972). The interrelation of biting and filtering in the feeding activity of the northern anchovy (Engraulis mordax). J. Fish. Res. Bd Can. 29: 285-293

O'Connell, C. P., Zweifel, J. R. (1972). A laboratory study of particulate and filter feeding of the Pacific mackerel, Scomber japonicus. Fish. Bull., Wash. 70: 973-981

Parr, A. E. (1930). Is the presence of phytoplankton in the stomach contents of the Californian sardine caused by special pursuit or merely due to incidental ingestion? Ecology 11: 155-180

Parsons, T. R., Maita, Y., Lalli, C. M. (1984). A manual of chemical and biological methods for seawater analysis. Permagon Press, Oxford

Pillar, S. C. (1986). Temporal and spatial variations in copepod and euphausiid biomass off the southern and south-western coasts of South Africa in 1977/78. S. Afr. J. mar. Sci. 4: 219-229

Robinson, G. A. (1966). A preliminary report on certain aspects of the biology of the South African anchovy, Engraulis capensis (Gilchrist). M. Sc. thesis, University of Stellenbosch, South Africa

Shannon, L. V., Field, J. G. (1985). Are fish stocks food limited in the southern Benguela pelagic ecosystem? Mar. Ecol. Prog. Ser. 22: 7-19

Shannon, L. V., Pillar, S. C. (1986). The Benguela ecosystem. III. Plankton. In: Barnes, M. (ed.) Oceanogr. mar. biol. A. Rev. 24: 65-170

Shelton, P. A. (1986). Fish spawning strategies in the variable southern Benguela Current region. Ph. D. thesis, University of Cape Town, South Africa

Strickler, J. R. (1985). Feeding currents in calanoid copepods: two new hypotheses. In: Laverack, M. S. (ed.) Physiological adaptations of marine animals. Symp. Soc. Exp. Biol. 39: $459-485$

Verheye, H., Hutchings, L. (1988). Horizontal and vertical distribution of zooplankton biomass in the Southern Benguela upwelling region, May 1983. S, Afr. J. mar. Sci. 6: 255-265

Warshaw, S. J. (1972). Effects of Alewives (Alosa pseudoharengus) on the zooplankton of Lake Wononskopomuc, Connecticut. Limnol. Oceanogr. 17: 816-825

Zar, J. H. (1984). Biostatistical analysis, second edition. McElroy, W. D., Swanson, C. P. (eds.) Prentice Hall Biological Science Series, Prentice Hall, New Jersey

This article was submitted to the editor; it was accepted for printing on September 28, 1988 